\title{
THE SYSTEMATIC WOOD ANATOMY OF THE MORACEAE (URTICALES) IV. GENERA OF THE TRIBE MOREAE WITH URTICACEOUS STAMENS*
}

\author{
by
}

B. J. H. ter Welle, J. Koek-Noorman and S. M. C. Topper

Institute of Systematic Botany, University of Utrecht, Heidelberglaan 2, 3508 TC Utrecht, The Netherlands

Summary

The wood anatomy of the genera of the tribe Moreae with urticaceous stamens, viz. Broussonetia, Maclura s.l. (including Cardiogyne, Chlorophora, and Cudrania), Malaisia, Milicia, Morus, Olmedia, Pachytrophe, Plecospermum, Sloetiopsis, Streblus s.1. (including Paratrophis, Phyllochlamys, Pseudostreblus, and Sloetia), and Trophis s.l.(including Calpidochlamys and Maillardia), is described in detail. Separate descriptions have been made for sections and/or subgenera to facilitate the discussion about the generic delimitations made by several taxonomists. The following generic combinations previously proposed by taxonomists are supported by wood anatomical features: Broussonetia + Allaeanthus; Maclura + Chlorophora + Cardiogyne + Cudrania + Plecospermum. The segregation of the African species of Chlorophora in a separate genus Milicia is supported by wood anatomical evidence. The broad genus concept of Streblus and Trophis is not supported by wood anatomy. Several sections of these genera should be reinstated as genera. The correlations between wood anatomy, latitude, habit and habitat are discussed as far as allowed by the material studied. Characters useful for the delimitation of the genera proved to be the size of the intervascular pits, the parenchyma distribution, and the lengths of fibres and vessel elements. Rhombic crystals, vitreous silica and radial latex tubes usually are useful additional characters.

Key words: Moraceae, Moreae, Urticales, systematic wood anatomy.

\section{Introduction}

This paper is part of a series, in which the wood anatomy of the Moraceae is described and discussed in relation to the taxonomy of the family. The general outline of this study is provided in the first paper (Koek-Noorman et al., 1984).

The recent classification of the Moraceae by
Berg (1983) is followed here. He recognised 4 tribes: Dorstenieae, Castilleae, Moreae and Ficeae. The Moreae sensu Berg comprise all genera of the tribes Moreae and Artocarpeae sensu Corner (1962), and also a few genera assigned to the tribe Olmedieae sensu Corner (1962). This large tribe, comprising about $55 \%$ of all genera of the family, is subdivided into two groups of 9 and 12 genera, respectively. The most important difference between the two groups of the Moreae sensu Berg is found in the stamens: presence or absence of 'urticaceous' stamens, i.e., inflexed stamens which on flowering spring back elastically (Berg, 1973). The group of genera with urticaceous stamens, treated here, were described by. Berg (1983) as having inflorescences relatively simple; macrospermy to microspermy; diaspores dry, drupaceous or surrounded by a fleshy perianth, partly zoochorous; ecology predominantly marginal to rainforest conditions; taxonomically and geographically more or less coherent; centered in the Indo-Malaysian region, with transpacific connections.

In Berg's opinion this subdivision of the Moreae is very similar to groups recognised in the older classifications of the Moraceae. However, both Bentham and Hooker (1880) as well as Engler (1888) recognised only two tribes (subfamilies) in the Moraceae, viz. Moreae (Moroideae) and Artocarpeae (Artocarpoideae)! These two tribes consequently also include the tribes Ficeae, Dorstenieae and Castilleae (or Olmedieae) as recognised by both Berg (1983) and Corner (1962).

From the foregoing it will be evident, that the delimitation of the Moraceae tribes, and especially of the group of the Moreae and Artocarpeae is extremely difficult. For practical reasons the delimitation of the tribes and genera as presented by Berg (1983) is followed here. The group of genera treated in this paper is characterised by the presence of urticaceous stamens. Included are the following genera:

- This project was made possible by a grant of BION-ZWO (14.45-01). 


\begin{tabular}{|c|c|c|c|c|}
\hline genus & & \multicolumn{2}{|l|}{ including } & geographic distribution \\
\hline Ampalis & & & - & Madagascar \\
\hline Bleekrodea & & & - & Madagascar and Malesia \\
\hline Broussonetia & - & Broussonetia & - & Temperate and tropical Asia \\
\hline & - & Allaeanthus & - & Madagascar and Asia \\
\hline Fatoua & & & - & Madagascar and Asia \\
\hline Maclura & - & Maclura & - & Temperate and tropical America \\
\hline & - & Cardiogyne & - & Southeast Africa \\
\hline & - & Chlorophora & - & Tropical America \\
\hline & - & Cudrania & - & Asia and Australia \\
\hline & - & Plecospermum & - & India and Thailand \\
\hline Malaisia & & & - & Southeast Asia and Australia \\
\hline Milicia & & & - & Tropical Africa \\
\hline Morus & & & - & Temperate northern hemisphere and Pantropical \\
\hline Pachytrophe & & & - & Madagascar \\
\hline Streblus & - & Streblus & - & Southeast Asia \\
\hline & - & Paratrophis & - & Asia and Australia \\
\hline & - & Phyllochlamys & - & Asia \\
\hline & - & Pseudostreblus & - & Asia, mainland \\
\hline & - & Sloetia & - & Malaya and Sumatra \\
\hline & - & Sloetiopsis & - & Tropical Africa \\
\hline Trophis & - & Trophis & - & Tropical America \\
\hline & - & Calpidochlamys & - & Asia \\
\hline & - & Maillardia & - & Madagascar and Réunion \\
\hline & - & Olmedia & - & Tropical America \\
\hline
\end{tabular}

Berg (1983) mainly followed the broad genus concepts of Corner (1962). However, he hesitated to accept the inclusion of Maillardia and Calpidochlamys in Trophis, and of Sloetia and Sloetiopsis in Streblus (pers. comm.). On the other hand, Corner (1962) did not include Olmedia in Trophis, and Plecospermum in Maclu$r a$, but gave these taxa the rank of genus. The genus Milicia was reinstated by Berg (1982) to accommodate the two African species of Chlorophora.

\section{Methods and Materials}

The methods are described in the first paper of this series (Koek-Noorman et al., 1984). The ray types mentioned in the descriptions, follow the definitions of Kribs (1968). The wood samples of the African genera are generally backed by herbarium vouchers identified by Dr. C.C. Berg; this also applies to the samples of the Neotropical genus Olmedia. The samples of the Asian genera are generally backed by herbarium vouchers, but the genus and species names have not been checked recently. Details on individual wood samples are provided at the beginning of each generic description. In total 114 samples were studied. Wood samples of Ampalis, Bleekrodea, and Fatoua were not available for this study. In the descriptions, averages are given for percentage of solitary vessels, numbers of vessels per sq. $\mathrm{mm}$, diameter of the vessels, ves-

sel member length, fibre wall thickness and lumen diameter, fibre length and $F / V$-ratio (i.e., fibre length/vessel member length), the number of rays per $\mathrm{mm}$. The other quantitative data represent minimum and maximum values. The data on specific gravity are based on the samples cited under 'Material studied', complemented with data of samples in the Utrecht wood collection not further included in the anatomical study.

\section{Generic descriptions}

\section{Broussonetia L'Hér. ex Vent.}

Broussonetia sect. Allaeanthus (Thw.) Corner (Table 1; Figs. 1, 3)

According to Corner (1962) this section comprises three species, $B$. kurzii, $B$. luzonica, and $B$. zeylanica. Corner (1962) included Allaeanthus in Broussonetia, reducing this taxon to a section. The combination Broussonetia greveana was made by Berg (1977a). Originally, this taxon was assigned to Ampalis by Baillon (1895) as $A$. greveana. However, Léandri (1948) transferred this taxon to Chlorophora. Corner (l.c.) made the combination Maclura greveana as a species of the section Chlorophora. More recently, Capuron (1972) placed it in Allaeanthus, near A. zeylanica. 


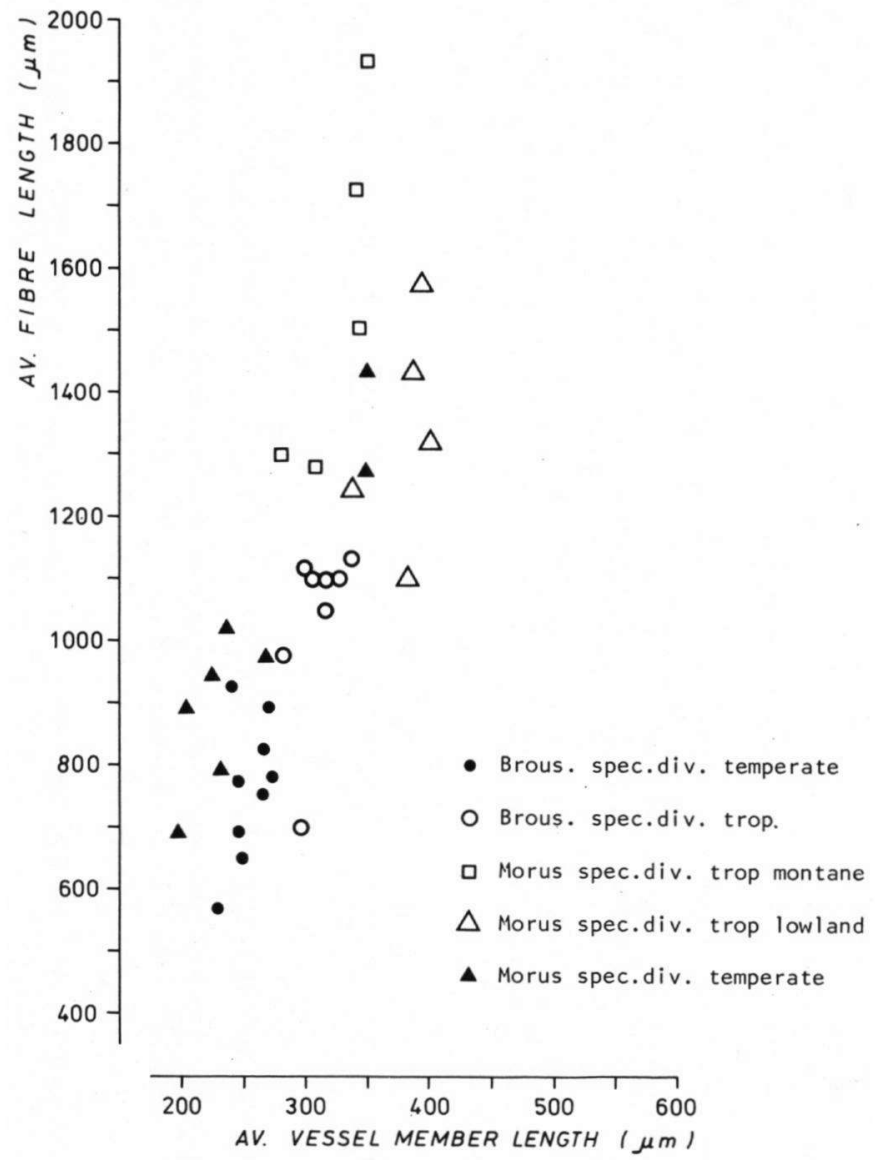

Fig. 1. Element length of Morus and Broussonetia species.

Broussonetia greveana is restricted to Madagascar and the Comore Islands. The other species are distributed from Sri Lanka to Malesia. The trees (or liana, B. kurzii) of the Asian species are found in lowland rainforests, up to 200-400 m altitude. Broussonetia greveana prefers dry forests or thickets or occurs along streams, from sea level up to $800 \mathrm{~m}$ altitude.

Material studied: $B$. greveana (Baillon) C.C. Berg. Madagascar: C.T.F.T. 59 (Uw 26758), via Wageningen no. 148 (Uw 26759), Somely (= Vory) s.n. (Uw 26760). - B. kurzii (Hook.f.) Corner. Thailand : ex Lw (Uw 26754). - B. luzonica (Blanco) Bureau. Philippines: A.N. Green F.P.R. I. 1165 (Uw 24210); Indonesia: AL 22231 (Uw 24432); locality unknown, ex WDw 416/2531 (Uw 24611).

General features: Growth rings absent or faint; heartwood light brown to brown, not well defined from the paler cream sapwood. Texture coarse, grain slightly interlocked. Specific gravity $460-630 \mathrm{~N}$ per cubic metre.

Microscopic fe a tures: Vessels diffuse, solitary $(55-70 \%)$ and in short radial multiples of $2-4 ; 5-9(-16)$ per sq. $\mathrm{mm}$, round to oval, diameter 155-215 $\mu \mathrm{m}$, vessel member length 280-335 $\mu \mathrm{m}$. Perforations simple, end walls almost transverse. Intervascular pits alternate, round, oval to polygonal, 4-9 $\mu \mathrm{m}$. Vessel-ray and vessel-parenchyma pits larger and irregularly shaped, half-bordered, the borders sometimes reduced. Thin-walled tyloses present. Fibres nonseptate, with small simple pits restricted to the radial walls; walls $1-3 \mu \mathrm{m}$, lumina $8-16$ $\mu \mathrm{m}$, occasionally gelatinous; length $980-1130$ $\mu \mathrm{m} ; \mathrm{F} / \mathrm{V}$-ratio 3.3-3.7. Rays uniseriate and multiseriate, heterogeneous type II/III, 3-5 per $\mathrm{mm}$. Uniseriate rays $0-5 \%$, composed of 


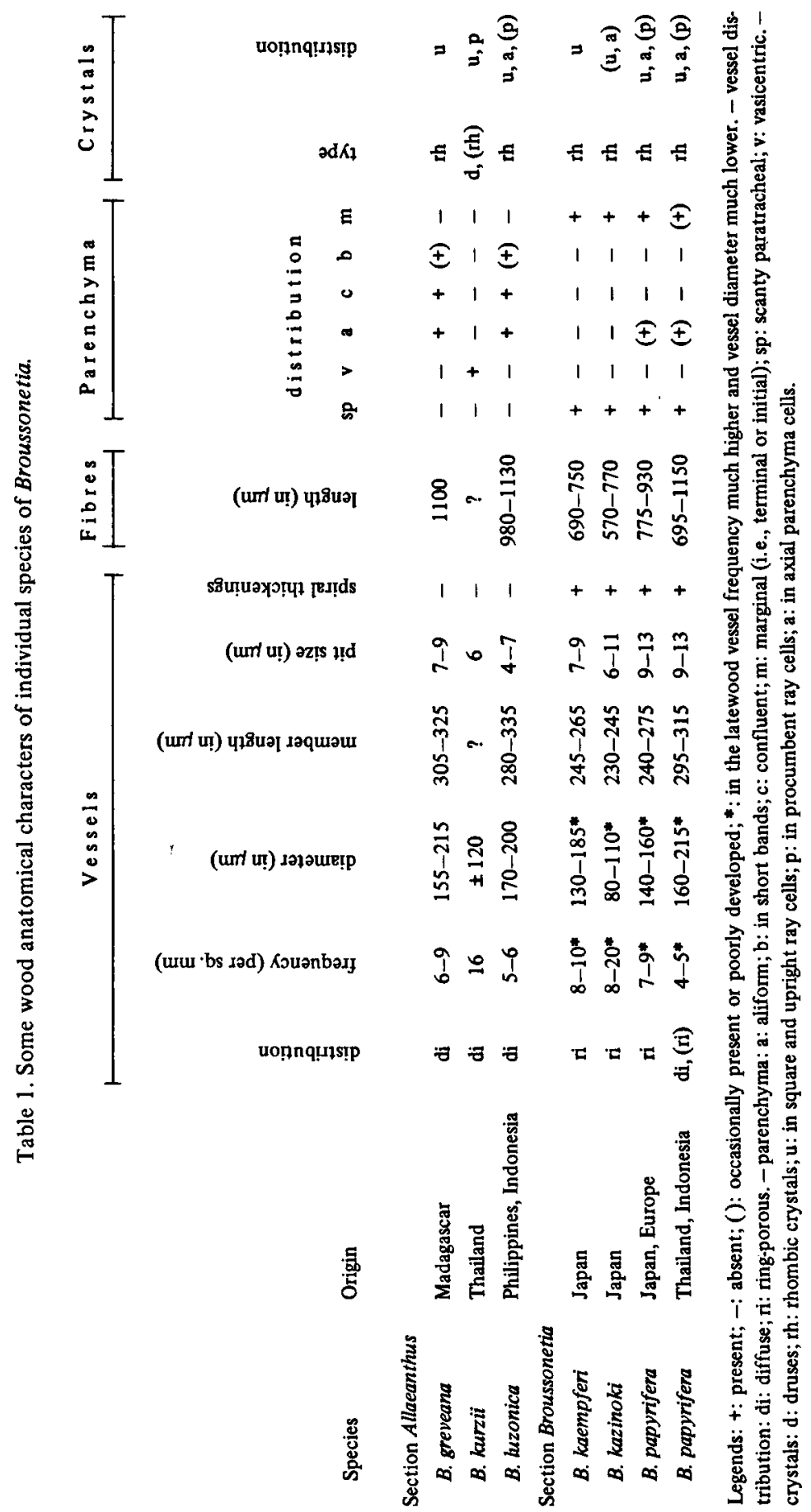


procumbent and upright cells, height up to 12 cells $(120-185 \mu \mathrm{m})$. Multiseriate rays composed of procumbent cells except for the uniseriate margins of $1-2$ rows of square and/or upright cells; $2-6$ cells wide, up to $600(-1300) \mu \mathrm{m}$ high (in $B$. luzonica up to 280-350 $\mu \mathrm{m}$ ); occasionally with some sheath cells. Parenchyma aliform and aliform-confluent, sometimes in short bands; in the sample of $B$. kurzii only narrow vasicentric parenchyma present. Parenchyma strands of 3-4 cells. Rhombic crystals in the marginal ray cells, and occasionally in the procumbent ray cells and the axial parenchyma. Radial latex tubes present, sometimes few, diameter 20-45 $\mu \mathrm{m}$, (much) larger than the surrounding ray cells in tangential section.

Note: Broussonetia kurzii shows druses and few rhombic crystals in the ray cells. As only sections of this species were available, data on element length cannot be provided.

\section{Broussonetia sect. Broussonetia (Table 1; Figs. 1, 4-8)}

This section comprises four species (Corner, 1962), distributed in Asia. Broussonetia papyrifera has been introduced into temperate and tropical areas outside its natural distribution area. Small trees or trees up to $35 \mathrm{~m}$, mainly in subtemperate forests, or the more seasonal parts of tropical forests.

M a terial st udied: $B$. kaempferi Siebold. Japan: FOFw (Uw 26981), TWTw 532 (Uw 26782). - B. kazinoki Siebold. Japan: T. Kishima 715 (Uw 26764), S. Okamoto 836 (Uw 26765), FOFOw 7424 (Uw 26979), TWTw 331 (Uw 26783). - B. papyrifera (L.) Vent. Japan: TWTw 70 (Uw 26784); Thailand: Kasin 392 (Uw 24338); Indonesia: IND. col. 9400 (Uw 26750); Netherlands (cult.): Cantonspark 4718 (UNw 213), Wagen. Arb. C 10668 (Uw 26761); loc. unknown: s.n. (Uw 26753).

General features: Growth rings mostly distinct; colour light brown to cream, no demarcation between sapwood and heartwood. Texture medium to coarse, grain straight. Specific gravity 360-650 N per cubic metre.

Microscopic features: Wood mostly ring-porous. Vessels solitary (40-80\%) and in short radial multiples of 2-4 (in the latewood irregular clusters of few to 50 narrow vessels, diameter $10-50 \mu \mathrm{m}) ; 4-20$ per sq. mm, round to oval, diameter $80-215 \mu \mathrm{m}$, vessel member length 230-315 $\mu \mathrm{m}$. Perforations simple, end walls almost transverse. Intervascular pits alternate, round, oval to polygonal, $6-13 \mu \mathrm{m}$. Vessel-ray and vessel-parenchyma pits larger and irregularly shaped, half-bordered, the borders sometimes reduced. Thin-walled tyloses present. Spiral thickenings in the latewood vessels common. Fibres nonseptate, with small simple pits restricted to the radial walls; walls $1-3$ $\mu \mathrm{m}$, lumina 5-20 $\mu \mathrm{m}$, occasionally gelatinous; length 570-1150 $\mu \mathrm{m} ; \mathrm{F} / \mathrm{V}$-ratio $2.5-3.8$. Rays uniseriate and multiseriate, heterogeneous II/ III, $7-9$ per mm. Uniseriate rays $0-15 \%$, composed of procumbent and upright cells, height up to $4-8(-25)$ cells $(130-160$, sporadically $420 \mu \mathrm{m}$ ). Multiseriate rays composed of procumbent cells except for the uniseriate margins of 1-3 square and/or upright cells; $3-5(-7)$ cells wide, up to 410-510 $\mu \mathrm{m}$ high; occasionally with some sheath cells. Parenchyma scanty paratracheal, occasionally aliform with short wings, and in initial bands up to 20 cells wide. Parenchyma strands of 3-4 cells. Rhombic cryscommon, restricted to the marginal ray cells, or distributed over the entire ray, and in the axial parenchyma. Radial latex tubes scarce or absent, diameter $20 \mu \mathrm{m}$, only slightly larger than the surrounding ray cells in tangential section.

Note: The tropical samples of $B$. papyrifera show less distinct growth rings (Uw 26750) or no growth rings at all (Uw 24338).

\section{Maclura Nutt.}

The genus Maclura s.l. in the classification of Corner (1962) consists of four sections: Cardiogyne, Chlorophora, Cudrania, and Maclura. Before then, these sections were considered as separate genera. Berg (1977a) modified this broad genus concept. In his opinion Plecospermum, treated as a separate genus by Corner (1962), should be included in Maclura s.l. Berg (1977a) also mentioned that Chlorophora excelsa and $C$. regia should be excluded from Maclura s.1., and consequently transferred them to Milicia (Berg, 1982). Chlorophora tinctoria remained included in Maclura s.l., although Kaastra (1972) preferred the genus rank for this taxon.

\section{Maclura sect. Cardiogyne (Bureau) Corner}

(Table 2; Figs. 2, 9)

A section with one species, $M$. africana (Berg, 1977 a). In his discussion on the taxonomic position of $M$. brasiliensis, Kaastra (1973) considered this taxon congeneric with Cardiogyne africana and Maclura pomifera (sect. Maclura sensu Corner). Berg (1977a) does not follow this idea, although he states that Cardiogyne is closely related to and probably even congeneric with Maclura s.s. In this paper, Cardiogyne is considered as a section of Maclura with only one species, whereas $\boldsymbol{M}$. brasiliensis is treated under Maclura sect. Maclura. Maclura africana is distributed in southern Africa as evergreen shrubs or treelets, up to $7 \mathrm{~m}$ high, in coastal scrubs, on riverbanks or even rainforests, from sea level up to $1000 \mathrm{~m}$ altitude. 


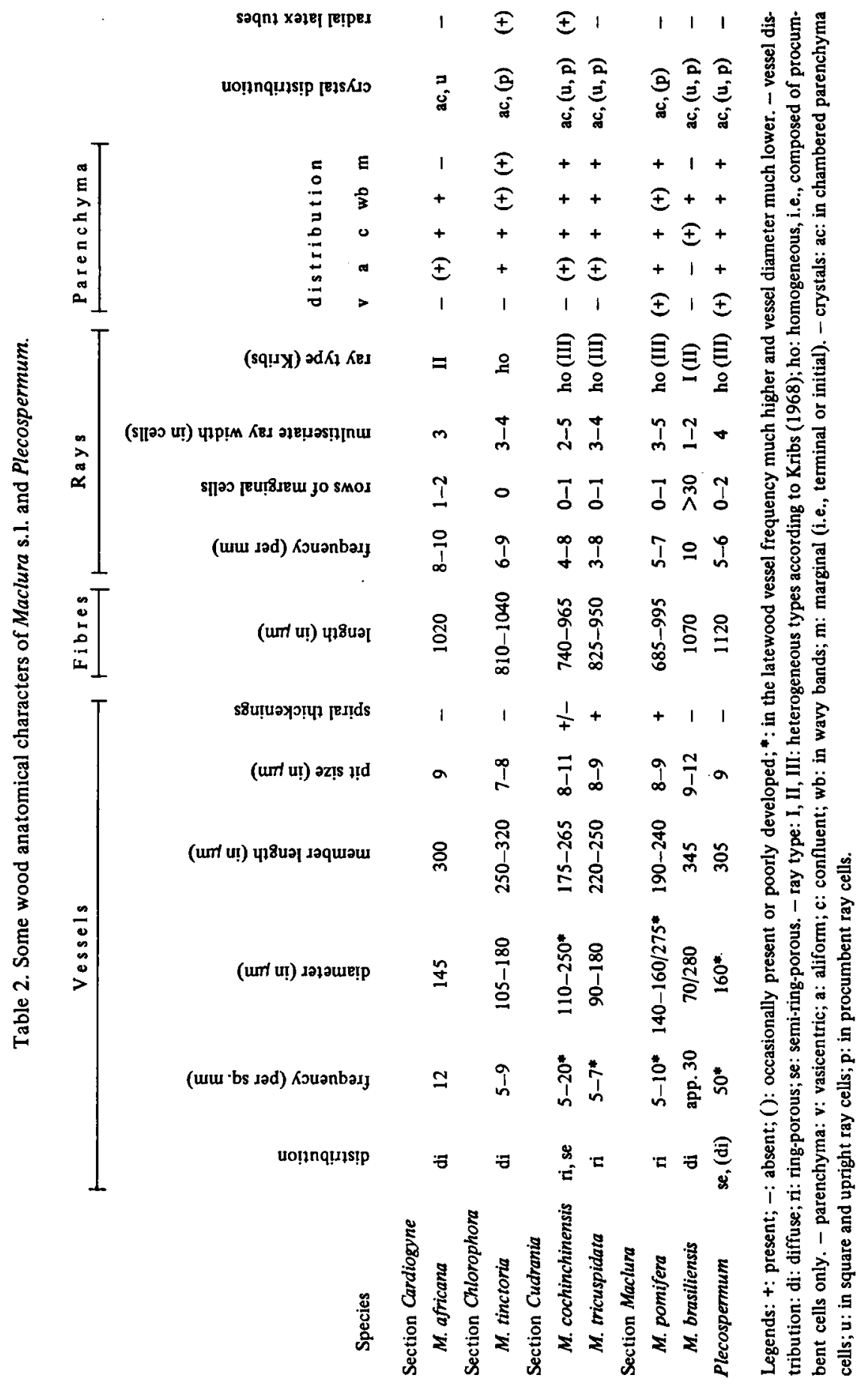




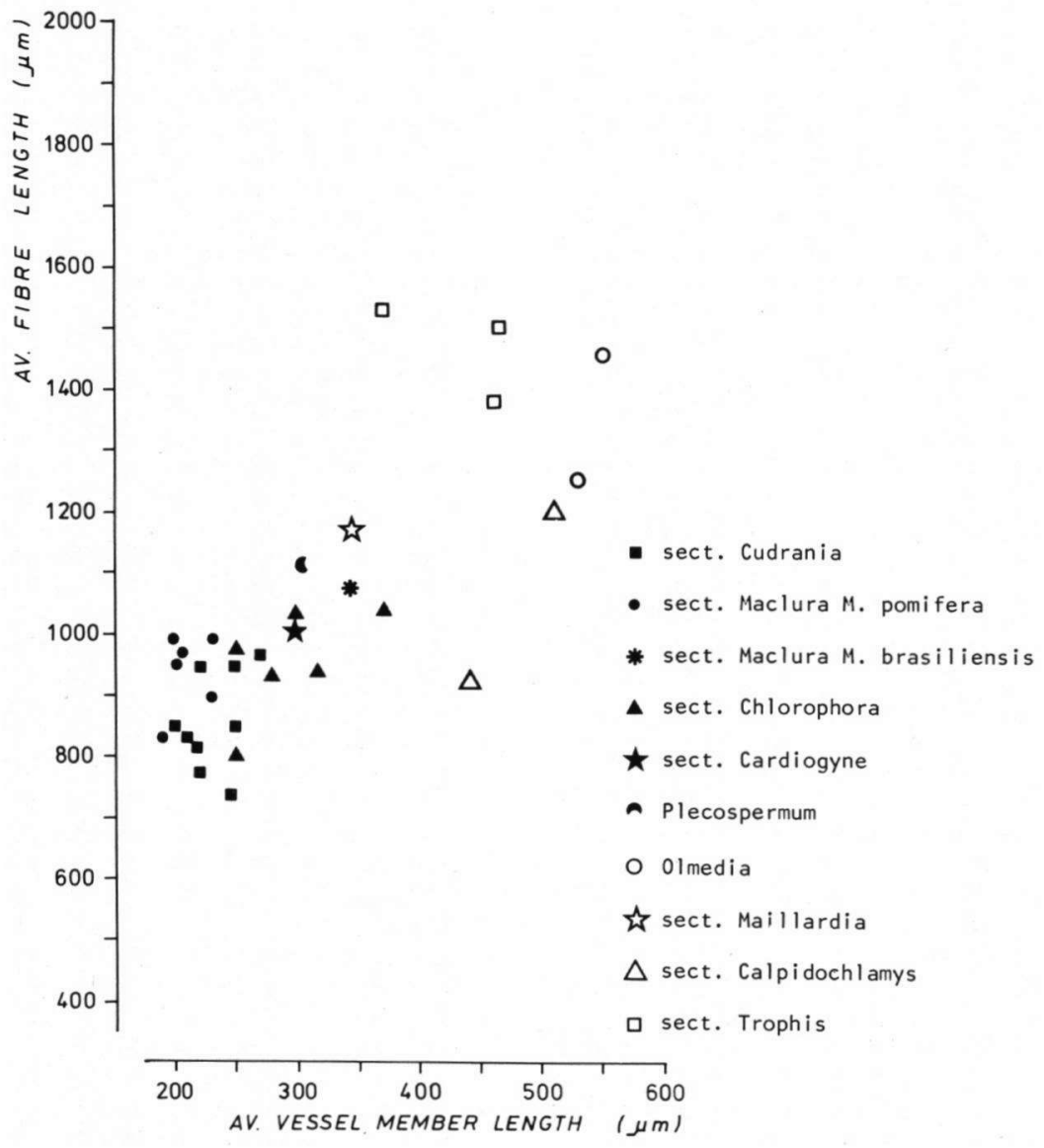

Fig. 2. Element length of Maclura s.1. and Trophis s.1., including Plecospermum and Olmedia.

Material studied: $M$. africana (Bureau) Comer. Zimbabwe, Botanical Garden, Harare: Berg s.n. (Uw 27394).

General features: Growth rings absent, sapwood white to yellow, heartwood not available. Texture coarse, grain straight. Specific gravity $570 \mathrm{~N}$ per cubic metre.

Microscopic features: Vessels diffuse, solitary $(25 \%)$ and in radial multiples of $2-7$ and some irregular clusters of $2-3 ; 12$ per sq. $\mathrm{mm}$, round to oval, diameter $145 \mu \mathrm{m}$, vessel member length $300 \mu \mathrm{m}$. Perforations simple, end walls almost transverse. Intervascular pits alternate, round, oval or polygonal, $9 \mu \mathrm{m}$. Vessel-ray and vessel-parenchyma pits larger and irregularly shaped, half-bordered, the borders sometimes reduced. Thin-walled tyloses common. Fibres nonseptate, with small pits restricted to the radial walls; walls $3-4 \mu \mathrm{m}$, lumina 5 $\mu \mathrm{m}$; length $1020 \mu \mathrm{m} ; \mathrm{F} / \mathrm{V}$-ratio 3.4. Rays uniseriate and multiseriate, heterogeneous type II, $8-10$ per $\mathrm{mm}$. Uniseriate rays $30 \%$ composed of procumbent and upright cells, height up to 6 cells $(270 \mu \mathrm{m})$. Multiseriate rays composed of procumbent cells except.for the uniseriate margins of 1-2 rows of square and/or upright cells; 3 cells wide, up to $600 \mu \mathrm{m}$ high. Parenchyma aliform with short or long wings, often confluent and in wavy bands. Parenchyma strands of 3-4 cells. Rhombic crystals in the ray cells, and in the axial parenchyma in chambered cells, up to 4 crystals in axial rows.

Maclura sect. Chlorophora (Gaudich.) Bureau (Table 2; Figs. 2, 10-12)

Since Berg (1982) assigned the African species of this section to the reinstated genus Milicia Sim, the section comprises only one species 
(two additional species described in Chlorophora were previously transferred to Broussonetia by Berg, 1977a). The species is distributed in the Neotropics. The trees are up to $30 \mathrm{~m}$ high, and occur in various habitats from sea level up to $1600 \mathrm{~m}$ altitude.

Material st udied: $M$. tinctoria (L.) Don. Mexico: (Uw 25792); Panama: USw 664 (Uw 7135); Colombia: SJRw 1893 (Uw 18434); Venezuela: SJRw 10031 (Uw 18419); Brazil, Parana: Lindeman \& H. de Haas 1671 (Uw 13243), 1853 (Uw 13369); Argentina: Pederson 856 (Uw 26755), USw 458 (Uw 7107).

General features: Growth rings absent or faint; heartwood dark brown, sharply defined from the light brown sapwood. Texture medium to coarse, grain interlocked. Specific gravity $600-970 \mathrm{~N}$ per cubic metre.

Micr oscopic feat ures: Vessels diffuse, solitary $(40-55 \%)$ and in short radial multiples, and few irregular clusters of $2-4(-8) ; 5-9$ per sq. mm, round to oval, diameter $105-180 \mu \mathrm{m}$, vessel member length $250-320 \mu \mathrm{m}$. Perforations simple, end walls almost transverse. Intervascular pits alternate, round, oval and polygonal, 7-8 $\mu \mathrm{m}$. Vessel-ray and vessel-parenchyma pits larger, elongated, more irregularly shaped, half-bordered, the borders commonly very reduced. Thin-walled tyloses abundant. Fibres nonseptate, with small simple pits restricted to the radial walls; walls $3-4 \mu \mathrm{m}$, lumina $4-9 \mu \mathrm{m}$, occasionally gelatinous; length $810-$ $1040 \mu \mathrm{m} ; \mathrm{F} / \mathrm{V}$-ratio 2.9-3.9. Rays uniseriate and multiseriate, homogeneous, rarely heterogeneous type III, 6-9 per $\mathrm{mm}$. Uniseriate rays $0-5 \%$, composed mainly of procumbent cells and few square and/or upright cells, height up to $1-5$ cells $(60-120 \mu \mathrm{m})$. Multiseriate rays composed of procumbent cells only; 3-4 cells wide, up to $170-400 \mu \mathrm{m}$ high. Parenchyma aliform, with short and long wings, occasionally abaxially unilateral, confluent, occasionally in wavy bands, and occasionally in narrow terminal bands. Parenchyma strands of 2-7 cells. Rhombic crystals abundant in the axial parenchyma, in crystalliferous strands containing up to 15 crystals, one crystal per chamber; occasionally also in the ray cells.

Note: Radial and axial latex tubes were observed in only one sample (Uw 7107 from Argentina).

\section{Maclura sect. Cudrania (Trécul) Corner (Table 2; Figs. 2, 13-16)}

A section with five species, which are distributed through Asia, Australia, and Japan. The habit is variable ranging from shrubs and trees to climbers. The two species studied here show a different distribution and habit. Maclura cochinchinensis is found from Sri Lanka and India to China and Japan, and throughout the Malesian Archipelago, as climbers in lowland forests and occasionally up to $1800 \mathrm{~m}$ altitude. Maclura tricuspidata is distributed in the humid temperate part of Central China and Korea, as trees or shrubs.

Material studied: $M$. cochinchinensis (Lour.) Corner. India: Gamble 0.5006 (Uw 18395), 0.5007 (Uw 18396); China: Y. Tang 0526, ex SJRw 21994 (Uw 18420); Indonesia: Woodworth 4609 (Uw 24256), Volkers XI B 327 (Uw 25799), XI B 286 (Uw 25798); Australia, Queensland: F.P.R.L.18982 (Uw 18521). - M. tricuspidata Carr. China: F.P.R.L. 14677 (Uw 18385); U.K. (cult.): Kew, Temperate House (Uw 18397).

General features: Growth rings distinct in the wood samples of the temperate regions ( $M$. tricuspidata, and part of $M$. cochinchinensis); heartwood dark brown, sharply defined from the light brown sapwood. Texture medium to coarse, grain straight. Specific gravity $750-950 \mathrm{~N}$ per cubic metre.

Microscopic features: Wood ring-porous to semi-ring-porous, tending to diffuseporous in the samples from tropical areas. Vessel(s) solitary $(18-52 \%)$ and in short radial multiples and irregular clusters of $2-4$ (in the latewood up to 12$) ; 5-20(-50)$ per sq. mm, round to oval, diameter 90-250 $\mu \mathrm{m}$ (in the earlywood up to $400 \mu \mathrm{m}$ ), vessel member length 175-265 $\mu \mathrm{m}$. Perforations simple, end walls almost transverse. Intervascular pits alternate, round, oval and polygonal, 8-11 $\mu \mathrm{m}$. Vesselray and vessel-parenchyma pits larger, elongated, irregularly shaped, half-bordered, the borders in part reduced, occasionally unilaterally compound. Thin-walled tyloses abundant. Fibres nonseptate, with small simple pits restricted to the radial walls; 2-3 $\mu \mathrm{m}$, lumina 5-7 $\mu \mathrm{m}$, occasionally gelatinous; length $740-950 \mu \mathrm{m} ; \mathrm{F} / \mathrm{V}$ ratio 3.1-4.3 Rays uniseriate and multiseriate, homogeneous and occasionally heterogeneous type III, 3-8 per $\mathrm{mm}$. Uniseriate rays $5-48 \%$, composed of procumbent and some square and/or upright cells, height $3-5(-12)$ cells $(80-240 \mu \mathrm{m})$. Multiseriate rays composed of procumbent cells, and only occasionally with $1-2(-4)$ rows of uniseriate margins of square and/or upright cells; $2-5$ cells wide, up to 540$1200 \mu \mathrm{m}$ high. Occasionally with some sheath cells. Parenchyma aliform with short or long wings, confluent, and sometimes wavy, resulting in a reticulate pattern; in the prominently ring-porous samples initial bands including the larger pores of the earlywood. Parenchyma strands of $2-4(-5)$ cells. Rhombic crystals abundant in the axial parenchyma, in crystalli- 
ferous strands containing up to 14 crystals, one crystal per chamber or cell, few crystals in the rays.

Notes: Spiral thickenings were observed in both samples of $M$. tricuspidata and one sample of $M$. cochinchinensis (Uw 18420 from China). Radial latex tubes, diameter $25 \mu \mathrm{m}$ and much larger than the surrounding ray cells in tangential section, and also axial latex tubes observed in one sample ( $U_{w} 24256$ ).

Maclura sect. Maclura (Table 2; Figs. 2, 17-19)

A section with two species, $M$. pomifera and $M$. brasiliensis. For details on the taxonomy see under Maclura sect. Cardiogyne. Maclura pomifera is a temperate species, native to the U.S.A. The trees or shrubs are up to $20 \mathrm{~m}$ high. Maclura brasiliensis is found in South and Central America and is said to have a liana-like habit.

Material studied: $M$. brasiliensis (Martius) Endl. Venezuela: Steyermark 61949 (Uw 26767). - $M$. pomifera (Raf.) C. Schneider. U.S.A.: locality unknown, USw 1531 (Uw 7227), USw 5843 (Uw 7441), USw 7391 (Uw 8462); A.F. Wilson s. n. (Uw 10222); Marts s.n. (Uw 24258); Israel (cult.): Woodworth 4 (Uw 24259); the Netherlands (cult.): (UNw 262); U.S.S.R. (cult.): (Uw 26769).

General features: Growth rings distinct in $M$. pomifera, absent in $M$. brasiliensis; heartwood dark golden brown, sharply defined from the light brown sapwood. Texture medium to coarse, grain slightly interlocked. Specific gravity $600-1000 \mathrm{~N}$ per cubic metre.

Microscopic features (mainly based on $M$. pomifera, see note): Wood ring-porous. Vessels solitary $(40-80 \%)$ and in short radial multiples and irregular clusters of 2-4 (in the latewood up to 10 ); 5-10 per sq. mm, round and oval, diameter 140-160 $\mu \mathrm{m}$ (in the earlywood up to $275 \mu \mathrm{m}$ ), vessel member length 190-240 $\mu \mathrm{m}$. Perforations simple, end walls almost transverse. Intervascular pits alternate, round, oval and polygonal, 8-9 $\mu \mathrm{m}$. Vessel-ray and vessel-parenchyma pits larger, elongated and irregularly shaped, half-bordered, often with reduced borders, sometimes unilaterally compound. Thin-walled tyloses abundant. Spiral thickenings commonly present, more prominent in the narrow latewood vessels. Fibres nonseptate, with small simple pits restricted to the radial walls; walls $3-4 \mu \mathrm{m}$, lumina $4-8 \mu \mathrm{m}$, occasionally gelatinous; length 685-995 $\mu \mathrm{m}$; F/V-ratio 3.5-5.0. Rays uniseriate and multiseriate, homogeneous, occasionally heterogeneous type III, 5-7 per $\mathrm{mm}$. Uniseriate rays $10-25 \%$, composed of procumbent cells and few square and/or upright cells, height up to $3-6(-12)$ cells $(100-240 \mu \mathrm{m})$. Multiseriate rays composed of procumbent cells, and only occasionally one marginal row of square or upright cells; 3-5 cells wide, up to $495-930 \mu \mathrm{m}$ high, sporadically with some sheath cells. $\mathrm{Pa}$ renchyma confluent, sometimes wavy, tending to short bands. Parenchyma strands of 2-5 cells. Rhombic crystals abundant to common in the axial parenchyma, in crystalliferous strands containing up to 15 crystals, one crystal per chamber or cell, occasionally few rhombic crystals in the rays.

Not es: In two samples (cult. UNw 262 and Uw 26769) crystals are lacking. Maclura brasiliensis deviates from the description in a number of mainly quantitative characters. This may be explained by the fact that the sample is of a limited diameter, it is the only sample from the tropics, and it is a liana. Main differences (next to the differences indicated in Table 2) are: F/V-ratio 3.1 ; uniseriate rays up to $35 \%$. Multiseriate rays $1-2$ cells wide and up to $1500 \mu \mathrm{m}$ high.

In $M$. pomifera the parenchyma distribution is also vasicentric, aliform, and marginal.

Plecospermum Trécul (Table 2; Figs. 2, 20, 21)

Corner (1962) regarded this taxon as a genus. Berg (1977a) placed it near Cardiogyne, and in 1983 suggested inclusion in Maclura s.1., but did not formally reduce it to a section of the latter genus. The genus comprises two species of climbers, found in tropical, rather dry habitats, and is distributed throughout India, Sri Lanka, Burma, Thailand, and the Andaman Islands.

Material studied: $P$. spinosum Trécul. India: For. Dept. 1878 E 487 (Uw 18400).

General features: Growth rings distinct; sapwood light brown, heartwood not available. Texture coarse, grain straight. Specific gravity $650 \mathrm{~N}$ per cubic metre.

Microscopic features: Wood semiring-porous to diffuse-porous. Vessels solitary (5\%) and in radial multiples (especially in the latewood), and some irregular clusters of $2-10$; up to 50 per sq. $\mathrm{mm}$, round to oval, diameter $160 \mu \mathrm{m}$, vessel member length $305 \mu \mathrm{m}$. Perforations simple, end walls almost transverse. Intervascular pits alternate, round, oval and polygonal, $9 \mu \mathrm{m}$. Vessel-ray and vessel-parenchyma pits larger, elongated, and irregularly shaped, half-bordered, the borders reduced, sometimes unilaterally compound. Thin-walled tyloses abundant. Fibres nonseptate, with small simple pits restricted to the radial walls; walls $2-3 \mu \mathrm{m}$, lumina 5-8 $\mu \mathrm{m}$; length $1120 \mu \mathrm{m} ; \mathrm{F} / \mathrm{V}$-ratio 3.7. Rays uniseriate and multiseriate. Homogeneous and occasionally heterogeneous type III, 5-6 per $\mathrm{mm}$. Uniseriate rays $5 \%$, composed of procumbent cells, and few square and/or up- 


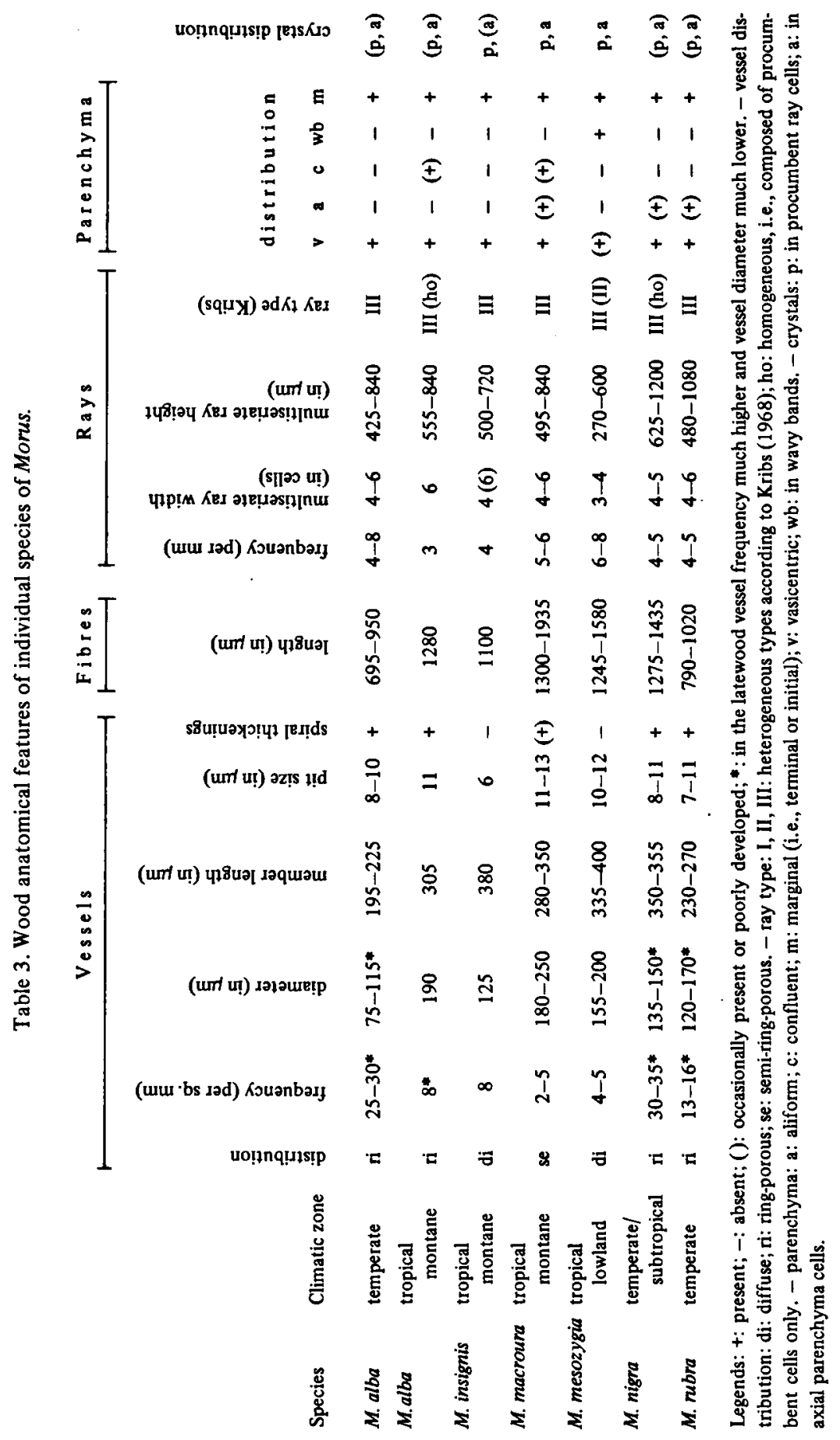


right cells, height up to 5 cells $(180 \mu \mathrm{m})$. Multiseriate rays composed of procumbent cells except for the uniseriate margins of $0-2$ rows of square and/or upright cells, these margins only sporadically present; 4 cells wide, up to 960 $\mu \mathrm{m}$ high. Occasionally with few sheath cells. Parenchyma rather abundant, vasicentric to aliform, confluent to reticulate, and as initial bands, 5-15 cells wide, and including the pores of the earlywood. Parenchyma strands of 1-2 cells. Rhombic crystals abundant in the axial parenchyma, often in crystalliferous strands containing up to 16 crystals, one crystal per chamber. Rhombic crystals also in the rays, but far less common, and also in the tyloses.

\section{Malaisia Blanco (Fig. 22)}

A monotypic genus (Corner, 1962), distributed throughout tropical Asia, from southern China, Thailand to Australia and the Fiji Islands. This woody climber, shrub or treelet is chiefly found in forest edges of the tropical lowland and swamp forests, up to $1200 \mathrm{~m}$ altitude.

Material studied: $M$. scandens (Lour.) Planchon. Australia: DFP 6608 (Uw 24362); locality unknown: ex MAD-SJRw 16710 (Uw 24630).

General features: Growth rings faint or absent; heartwood dark brown, sharply defined from the light brown sapwood. Texture coarse, grain interlocked. Specific gravity 700 $800 \mathrm{~N}$ per cubic metre.

Microscopic feat ures: Vessels diffuse, solitary (70-80\%) and in short radial multiples and irregular clusters of $2-4 ; 5$ per sq. $\mathrm{mm}$, round to oval, diameter $150-170 \mu \mathrm{m}$, vessel member length $440-470 \mu \mathrm{m}$. Perforations simple, end walls almost transverse. Intervascular pits alternate, round, oval to polygonal, 11-12 $\mu \mathrm{m}$. Vessel-ray and vessel-parenchyma pits larger, elongated, and irregularly shaped, halfbordered, the borders sometimes reduced. Thinwalled tyloses present. Fibres nonseptate, with small simple pits restricted to the radial walls; walls $3-4 \mu \mathrm{m}$, lumina $15 \mu \mathrm{m}$, occasionally gelatinous; length 1345-1495 $\mu \mathrm{m} ; \mathrm{F} / \mathrm{V}$-ratio 3.0-3.2. Rays uniseriate and multiseriate, heterogeneous type $\mathrm{II} / \mathrm{III}, 3-5$ per $\mathrm{mm}$. Uniseriate rays $15-17 \%$, composed of upright and square, and few procumbent cells, height up to 3-5 cells $(260-340 \mu \mathrm{m})$. Multiseriate rays composed of procumbent cells except for the uniseriate margins of 1-2 rows of upright and/or square cells; 3-4 cells wide, up to 570-840 $\mu \mathrm{m}$ high; occasionally with some sheath cells. Parenchyma vasicentric-aliform with short wings, only occasionally confluent. Parenchyma strands of 4 cells. Small quantities of vitreous silica present in the fibres and vessels. Radial latex tubes common, the diameter equal to the ray cells in tangential section, $10-15 \mu \mathrm{m}$.

\section{Milicia Sim (Fig. 23)}

Recently Berg (1982) reinstated the genus Milicia Sim, comprising the African species of Chlorophora, viz. $C$. regia and $C$. excelsa. Earlier in 1977 Berg had mentioned that $C$. regia and $C$. excelsa probably constituted a separate genus. Kloos (1982), using leaf anatomical features, came to the same conclusion. The species are distributed throughout tropical Africa, from Guinea-Bissau to Moçambique. The deciduous trees up to $35 \mathrm{~m}$ high are found in tropical lowland forests, ranging from rainforest to forest islands in savanna regions.

Material studied: $M$. excelsa (Welw.) C.C. Berg. Tanzania: Schlieben s.n. (Uw 6423); East Africa: Schlieben 11026 (Uw 15648). $M$. regia (A. Chev.) C.C. Berg. Guinea-Bissau: G-7 (Uw 5636); Ivory Coast: Leeuwenberg 2471 (Uw 6545).

General features: Growth rings absent or faint; heartwood light to dark brown, sharply defined from the yellowish sapwood. Texture coarse, grain straight to interlocked. Specific gravity $520-740 \mathrm{~N}$ per cubic metre.

Microscopic features: Vessels diffuse, solitary $(40-80 \%)$ and in short radial multiples or irregular clusters of $2-4 ; 1-7$ per sq. mm, round to oval, diameter $160-215 \mu \mathrm{m}$, vessel member length 350-400 $\mu \mathrm{m}$. Perforations simple, end walls almost transverse. Intervascular pits alternate, round, oval or polygonal, 10-12 $\mu \mathrm{m}$. Vessel-ray and vessel-parenchyma pits larger, and irregularly shaped, half-bordered, the borders sometimes very reduced. Thin-walled tyloses common. Fibres nonseptate, with small simple pits restricted to the radial walls; walls 3-4 $\mathrm{m}$, lumina 9-14 $\mathrm{m}$, occasionally gelatinous; length 1050-1425 $\mu \mathrm{m} ; \mathrm{F} / \mathrm{V}$-ratio 2.93.7. Rays uniseriate and multiseriate, heterogeneous type III, 4-6 per $\mathrm{mm}$. Uniseriate rays $0-15 \%$, composed of upright and square cells, height up to $2-5$ cells $(110-220 \mu \mathrm{m})$. Multiseriate rays composed of procumbent cells, with uniseriate margins of 1 , sporadically 2 rows of square and/or upright cells; $3-5(-6)$ cells wide, up to 315-460 $\mu \mathrm{m}$ high; occasionally with few sheath cells. Parenchyma aliform to confluent, and often in wavy bands, and occasionally marginal. Parenchyma strands of 3-4 cells. Rhombic crystals common in the square and upright marginal cells of the multiseriate rays and the uniseriate rays, always present in the axial parenchyma but far less common. Radial latex tubes, $25-50 \mu \mathrm{m}$ in diameter, (much) larger than the surrounding ray cells as seen in tangential section, infrequent, often absent. 
Morus L. (Table 3; Figs. 1, 24-32)

A recent monograph of Morus is not available. About 10 species are recognised. The genus is widespread, with species in the northern hemisphere (U.S.A., Europe, Japan, and China), and the tropical regions including Andes, Central America, Africa, and Indonesia. The trees, treelets or shrubs occur in various forest types, from sea level up to $2500 \mathrm{~m}$ altitude.

Material studied: $M$. alba $L$. The Netherlands (cult.): Cantonspark 4483 (UNw 309), Utrecht Bot. Gardens s.n. (UNw 716); South Africa: H. Baijnath s.n. (Uw 25505); India, Himalaya: Brandis 95H (Uw 25787). - M. celtidifolia H.B.K. U.S.A.: Barghoorn 8902 (Uw 9980). - M. insignis Bureau. Colombia: Cuatrecasas 18405 (Uw 24976). - M. macroura Miq. India, Assam: F.R.I. 75804 (Uw 24229); Indonesia, Java: Koorders 8742b (Uw 24425), 14193B (Uw 24426). - M. mesozygia Stapf ex A.Chev. Zaire: Wermuth s.n. (Uw 18763); Nigeria: F.H.I. 3956 (Uw 18399); West Africa: MSP 36 (Uw 18398); Uganda: NO GM 39 (Uw 18522); Angola: s.n. (Uw 24513). - M. nigra L. The Netherlands: s.n. (UNw 43); Libanon: Schweinfurth 1 (Uw 25788). - M. rubra L. The Netherlands (cult.): Utrecht Bot. Gardens 72-199 (UNw 583); U.S.A.: USw W-3561 (Uw 7336), USw W- 4233 (Uw 7399).

General features: Growth rings distinct, faint or absent; heartwood brown to dark brown, sharply defined from the light cream sapwood. Texture medium to coarse, grain straight or weakly interlocked. Specific gravity $560-850 \mathrm{~N}$ per cubic metre.

Microscopic features: Wood ring-porous in the temperate species, faintly semi-ringporous to commonly diffuse-porous in the tropical species. Vessels solitary (17-60\%) and in short radial multiples or irregular clusters of 2-4 (in the latewood of the ring-porous species many irregular clusters of up to 8 pores); 2-35 per sq. $\mathrm{mm}$, and up to 100 per sq. $\mathrm{mm}$ in the latewood of the ring-porous samples, round to oval, diameter 75-250 $\mu \mathrm{m}$ (in the latewood as narrow as $30 \mu \mathrm{m}$ ), vessel member length 195-400 $\mu \mathrm{m}$. Perforations simple, end walls almost transverse. Intervascular pits round, oval and polygonal, 6-13 $\mu \mathrm{m}$. Vessel-ray and vesselparenchyma pits larger, elongated and irregularly shaped, half-bordered, the borders often reduced. Thin-walled tyloses common. Spiral thickenings present in the narrow vessels of the (semi-)ring-porous samples. Fibres nonseptate, with small simple pits restricted to the radial walls; walls $2-4 \mu \mathrm{m}$, lumina $6-20 \mu \mathrm{m}$, occasionally gelatinous; length $695-1935 \mu \mathrm{m} ; \mathrm{F} / \mathrm{V}$ ratio 2.9-5.5. Rays uniseriate and multiseriate, heterogeneous type III, occasionally type II or homogeneous, 3-8 per $\mathrm{mm}$. Uniseriate rays $2-23 \%$, composed of procumbent, square and/ or upright cells, height up to $3-12$ cells ( $100-$ $300 \mu \mathrm{m}$ ). Multiseriate rays composed of procumbent cells except for the uniseriate margins of 1-3 rows of square and/or upright cells; 4 6 cells wide, up to $425-1100 \mu \mathrm{m}$ high; occasionally with some sheath cells. Parenchyma paratracheal, varying from vasicentric to aliform-confluent and in confluent wavy bands, and apotracheal as marginal bands. Parenchyma strands of 2-4 cells. Rhombic crystals, predominantly in the uniseriate margins of the multiseriate rays and the uniseriate rays, in variable amounts, and few to scarce in the axial parenchyma.

Notes: In $M$. mesozygia the multiseriate rays are $3-4$ cells wide and up to $270-480 \mu \mathrm{m}$ high. Radial latex tubes, $30-45 \mu \mathrm{m}$ in diameter, and much larger than the surrounding ray cells (in tangential section) observed in one sample of $M$. mesozygia.

Details on the wood anatomical features of individual species are given in Table 3 and Fig. 1 .

\section{Olmedia Ruiz \& Pavon: see page 110.}

\section{Pachytrophe Bureau (Figs. 33, 34)}

Berg (1977a) revised the genus, and combined the two species recognised until that time into one species, $P$. dimepate. The genus is endemic to Madagascar. The trees or shrubs are up to $30 \mathrm{~m}$ high, and found in humid to dry forests, from sea level up to $1000 \mathrm{~m}$ altitude.

Material studied: $P$. dimepate Bureau. Madagascar: Veenendaal \& den Outer 1190 (Uw 26144), Thouvenot 23 (Uw 24257), U.P.J. 608, ex RBHw (Uw 26776).

General feat ures: Growth rings absent; heartwood light brown, not distinguishable from the sapwood. Texture medium, grain straight. Specific gravity $910-1000 \mathrm{~N}$ per cubic metre.

$\mathrm{Microscopic}$ feat ures: Vessels diffuse, solitary $(55-70 \%)$ and in short radial multiples and irregular clusters of $2-4 ; 3-7$ per sq. mm, round to oval, diameter $110-165 \mu \mathrm{m}$, vessel member length 355-515 $\mu \mathrm{m}$. Perforations simple, end walls almost transverse. Intervascular pits alternate, round, oval or polygonal, 7-9 $\mu \mathrm{m}$. Vessel-ray and vessel-parenchyma pits larger, elongated and irregularly shaped, halfbordered, the borders often very reduced. Thinwalled tyloses abundant. Fibres nonseptate with small simple pits restricted to the radial walls; walls 3-4 $\mu \mathrm{m}$, lumina $8-12 \mu \mathrm{m}$, occasionally gelatinous; length $1190-1460 \mu \mathrm{m}$; F/V-ratio 2.7-3.4. Rays uniseriate and multiseriate, heterogeneous type II, 3-5 per $\mathrm{mm}$. Uniseriate rays $10-25 \%$, composed almost ex- 
clusively of square and upright cells, height up to $4-9$ cells $(240-360 \mu \mathrm{m})$. Multiseriate rays composed of procumbent cells except for the uniseriate margins of 1-5 rows of square and/ or upright cells; 3-4 cells wide, up to 395$840 \mu \mathrm{m}$ high. Parenchyma predominantly in more or less concentric bands, $1.5-5$ per $\mathrm{mm}$, 3-6 cells wide, also scanty paratracheal, aliform with long and short wings, and occasionally confluent. Parenchyma strands of 3 cells. Rhombic crystals abundant in the ray cells, especially in the square and upright cells, less frequent in the procumbent cells and then smaller. Crystals occur occasionally also in the axial parenchyma and the tyloses.

\section{Plecospermum Trécul: see page 99.}

Sloetiopsis Engl.: see page 106.

\section{Streblus Lour.}

The delimitation of this genus is rather problematic. Corner (1962) included many taxa, formerly described as genera, as sections in Streblus s.l. As he had not studied the genus Sloetiopsis himself, he only mentioned the possibility that this genus might be closely related to Streblus sect. Sloetia. Neosloetiopsis, like Sloetiopsis native to Africa, is assigned to Streblus sect. Paratronhis by Corner (1962). Berg (1977a) monographed Sloetiopsis and Neosloetiopsis and placed the latter in the synonymy of Sloetiopsis. In the same paper he mentioned that Sloetiopsis and Sloetia may prove to be congeneric and may be regarded as related to Bleekrodea, another section of Streblus sensu Corner. In his classification of the Moraceae Berg (1983) assigned Streblus s.l. to the Moreae with urticaceous stamens; however, an indication of the taxa to be included was not given. Till today, Berg (pers. comm.) hesitates to include Sloetia and Sloetiopsis in Streblus, a continuing reflection of his statement (1977a) that Streblus s.l. appears to be too heterogeneous. Material of Corner's sections Paratrophis, Phyllochlamys, Pseudostreblus, Sloetia, and Streblus, as well as of Sloetiopsis was available for this study. The sections will be treated separately here because of the differences in the various classifications. The sequence of the sections is alphabetical, followed by Sloetiopsis.

\section{Streblus sect. Paratrophis (Blume) Corner}

The section comprises nine species in Asia, Polynesia, and Australia. Trees, $13-40 \mathrm{~m}$, occurring in various habitats, from sea level to montane areas. Two species were available for this study, viz. S. glaber and $S$. pendulinus. The ecology of these two species is strikingly dif- ferent. Streblus glaber is distributed in Malesia, Philippines, Indonesia and the Solomon Islands as trees up to $40 \mathrm{~m}$ high in montane forests from 700 to $2500 \mathrm{~m}$ altitude. Streblus pendulinus is distributed in the Pacific, Australia, and the eastern part of New Guinea as a shrub or tree of up to $13 \mathrm{~m}$ high, found in the lowland forests and along seashores. The wood anatomy of these two species differs in many features (Ter Welle, 1985). Because of these differences the species will be presented individually here.

\section{Streblus glaber (Table 4; Figs. 35, 36)}

Material studied: S. glaber (Merr.) Corner. Philippines: A.N. Green, F.P.R.I. 896 (Uw 24237); Indonesia: IND. col. E 3838 (Uw 24433), Irian Jaya: BW 9290 (Uw 20480), BW 11165 (Uw 20740), BW 7106 (Uw 21171), BW 7091 (Uw 24414).

General features: Growth rings absent; heartwood dark brown, well defined from the lighter sapwood. Texture medium, grain straight. Specific gravity $900-1090 \mathrm{~N}$ per cubic metre.

Microscopic feat ures: Vessels diffuse, solitary $(26-66 \%)$ and in short radial multiples and irregular clusters of $2-4 ; 3-6$ per sq. $\mathrm{mm}$, round to oval, diameter $150-220 \mu \mathrm{m}$, vessel member length $500 \mu \mathrm{m}$. Perforations simple, end walls almost transverse. Intervascular pits alternate, round, oval and polygonal, 8-11 $\mu \mathrm{m}$. Vessel-ray and vessel-parenchyma pits larger, elongated, and irregularly shaped, half-bordered, the borders usually very reduced. Thin-walled tyloses abundant, thick-walled tyloses scarce or absent. Fibres nonseptate with small (occasionally more prominent) simple pits restricted to the radial walls; walls $3-5 \mu \mathrm{m}$, lumina $8-15$ $\mu \mathrm{m}$, occasionally gelatinous; length $1360 \mu \mathrm{m}$; F/V-ratio 2.7. Rays uniseriate and multiseriate, heterogeneous type II, $5-8$ per $\mathrm{mm}$. Uniseriate rays $15-24 \%$, composed of square and upright cells and some procumbent cells, height up to 5-11 cells $(205-360 \mu \mathrm{m})$. Multiseriate rays composed of procumbent cells, except for the uniseriate margins of $1-5$ rows of square and/or upright cells; 3-4 cells wide, up to 440-960 $\mu \mathrm{m}$ high; occasionally with few sheath cells. Parenchyma scanty paratracheal, vasicentric, vasicentric-aliform with short and long wings, confluent and in wavy and often tangential bands. Parenchyma strands of 4 cells. Rhombic crystals in the upright and square cells, and occasionally also in the procumbent cells of the rays, and generally less abundant to scarce in the axial parenchyma cells in the same sample. Occasionally in chambered parenchyma cells in longitudinal rows of up to 6 crystals. Vitreous silica present in the fibres and sporadically in the axial parenchyma of some samples. 
Table 4. Some wood anatomical characters of Streblus s.l. and Sloetiopsis.

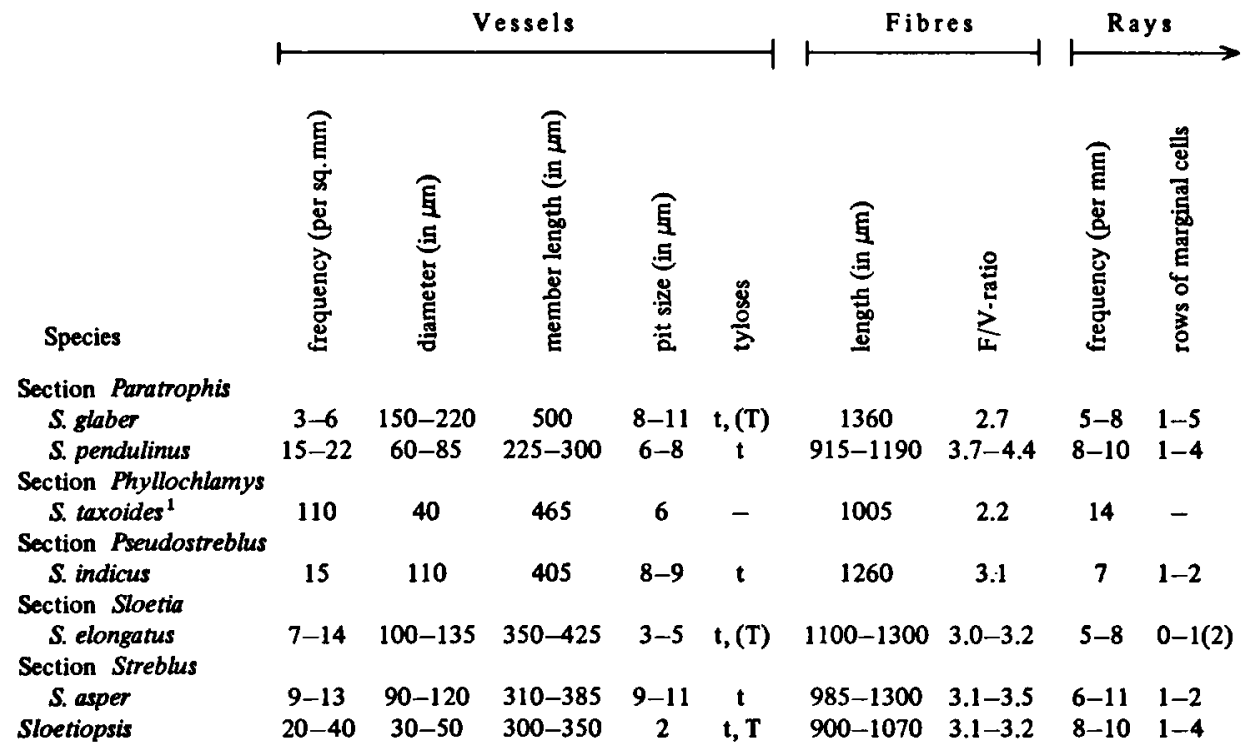

Legends: + : present; -: absent; (): occasionally present or poorly developed. - tyloses: $t$ : thin-walled; $T$ : thickwalled. - ray type: I, II, III: heterogeneous types according to Kribs (1968); ho: homogeneous, i.e., composed of procumbent cells only. - parenchyma: a: aliform; $\mathrm{c}$ : confluent; $\mathrm{cb}$ : in concentric bands; $\mathrm{v}$ : vasicentric; sp: scanty

Notes. Rhombic crystals are much more abundant in the samples from Irian Jaya than in those of the other provenances. Faint growth rings occur in Uw 24414, marked by differences in fibre wall thickness and lumen diameter.

Streblus pendulinus (Table 4; Figs. 37, 38)

Material studied: S. pendulinus (Endl.) F. Muell. U.S.A., Hawaii: Stern \& Herbst 2948 (Uw 18561); New Caledonia: s.n. (Uw 25784); Australia: D10 151-96 (Uw 24387), R-1139-33 (Uw 24388), R-535-21 (Uw 24389).

General feat ures: Growth rings absent; heartwood dark brown, the sapwood lighter brown to yellow. Texture medium, grain slightly interlocked. Specific gravity $700-900 \mathrm{~N}$ per cubic metre.

Microscopic features: Vessels diffuse, solitary $(20-41 \%)$ and in short radial multiples and irregular clusters of $2-6 ; 15-22$ per sq. $\mathrm{mm}$, round to oval, diameter $60-85 \mu \mathrm{m}$, vessel member length 225-300 $\mu \mathrm{m}$. Perforations simple, end walls almost transverse. Intervascular pits alternate, round or polygonal, 6-8 $\mu \mathrm{m}$. Vesselray and vessel-parenchyma pits larger, elongated and irregularly shaped, half-bordered, the borders in part reduced. Thin-walled tyloses com- mon. Fibres nonseptate, with small simple pits restricted to the radial walls; walls $2-4 \mu \mathrm{m}$, lumina 3-11 $\mu \mathrm{m}$, occasionally gelatinous; length 915-1190 $\mu \mathrm{m}$; F/V-ratio 3.7-4.4. Rays uniseriate and multiseriate, heterogeneous type II (III), 8-10 $\mu \mathrm{m}$ per $\mathrm{mm}$. Uniseriate rays $15-38$ $\%$, composed of square, upright and some procumbent cells, height up to 7-14 cells (175$340 \mu \mathrm{m}$ ). Multiseriate rays composed of procumbent cells except for the uniseriate margins of 1-4 rows of square and/or upright cells; $3-5$ cells wide, up to $450-950(-3000) \mu \mathrm{m}$ high; occasionally with some sheath cells. $\mathrm{Pa}$ renchyma scanty paratracheal and abundant as concentric bands, 3-14 cells wide, 2-4 per $\mathrm{mm}$. Parenchyma strands of $2-4$ cells. Rhombic crystals abundant in the axial parenchyma, less abundant in the square and upright ray cells, and only few in the procumbent ray cells. Vitreous silica in the vessels of some samples.

Note. A third species of Streblus sect. Paratrophis, viz. $S$. urophyllus Diels is represented by one sample (Indonesia, Irian Jaya: Kalkman 4938, Uw 18356). The parenchyma distribution and the absence of crystals matches completely the description of $S$. pendulinus. The number of vessels per $\mathrm{mm}$ falls within the range of $S$. glaber. Finally, the vessel diameter (96 
Table 4 (continued)

\begin{tabular}{|c|c|c|c|c|c|c|c|c|c|c|c|c|}
\hline & $\mathbf{R} \mathbf{a}$ & ys & & & & Pare & $n \operatorname{chy}$ & & & & & \\
\hline pecies & 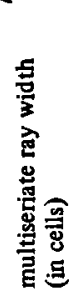 & 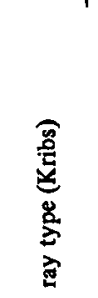 & sp & Dis & trib & utio & $c b \quad w b$ & 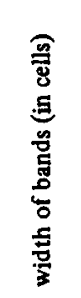 & 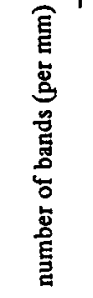 & 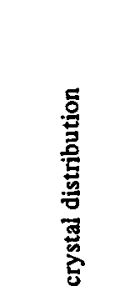 & 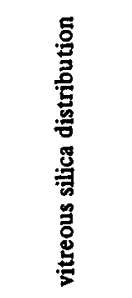 & 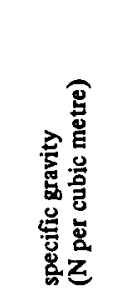 \\
\hline glaber & $3-4$ & II & $(+)$ & $(+)$ & $(+)$ & $(+)$ & $-(t)$ & - & - & $\mathrm{u}, \mathrm{p}, \mathrm{a}, \mathrm{ac})$ & (fi), (a) & $900-1090$ \\
\hline S. pendulinus & $3-5$ & II (III) & $(+)$ & - & - & - & +- & $3-14$ & $2-4$ & $\mathrm{u}, \mathrm{a},(\mathrm{p})$ & (ve) & $700-900$ \\
\hline S. taxoides ${ }^{1}$ & 2 & I & $(+)$ & - & - & - & +- & $2-3$ & 15 & $u, p, a, a c$ & - & - \\
\hline S. indicus & 2 & III & - & (+) & + & + & -+ & - & - & ac & - & $700-800$ \\
\hline S. elongatus & $2-3$ & Ill (ho) & - & + & + & $(+)$ & $-\quad-$ & - & - & a, ac & $(\mathrm{ve}),(\mathrm{fi}), \mathrm{a}$ & $900-1100$ \\
\hline $\begin{array}{l}\text { asper } \\
\text { loetiopsis }\end{array}$ & $\begin{array}{c}3-5 \\
3\end{array}$ & $\begin{array}{l}\text { III } \\
\text { II }\end{array}$ & $\begin{array}{l}(+) \\
(+)\end{array}$ & - & - & $\begin{array}{l}- \\
-\end{array}$ & $\begin{array}{l}+(+) \\
+\quad-\end{array}$ & $\begin{array}{c}8-12 \\
1\end{array}$ & $\begin{array}{c}1-3 \\
10-14\end{array}$ & $\overline{u, t}$ & $\begin{array}{l}\text { ve, (fi) } \\
\text { ve, (t) }\end{array}$ & $\begin{array}{l}500-750 \\
900-930\end{array}$ \\
\hline
\end{tabular}

paratracheal; wb: in wavy bands. - crystals: $u$ : in square and upright ray cells; $p$; in procumbent ray cells; $a$ : in axial parenchyma cells; ac: in chambered parenchyma cells; $t$ : tyloses. - silica (vitreous) distribution: a: axial parenchyma; fi: fibres; ve: vessels; $t$ : tyloses. ${ }^{1}$ ) based on immature sample only.

$\mu \mathrm{m})$ is intermediate between that of $S$. glaber and $S$. pendulinus, respectively. Corner, in his unpublished manuscript for the Flora Malesiana, states that the species $S$. urophyllus may be merely a high mountain form of $S$. glaber.

\section{Streblus sect. Phyllochlamys (Bureau) Corner} (Table 4)

A section with only one species, distributed from Sri Lanka, India, and Indochina to Malesia. Small, very shrubby trees in lowland forests in rocky or dry places. Only one sample was available for this study. The diameter of this sample is $0.4 \mathrm{~cm}$. Therefore only an incomplete wood anatomical description, and no details on general features can be provided.

Material studied: $S$. taxoides (Heyne) Kurz. Indonesia, Java: Bakhuizen van den Brink 2028 (Uw 26779).

Microscopic features. Vessels diffuse, solitary and in clusters or radial multiples. Perforations simple. Intervascular pits round or polygonal, $6 \mu \mathrm{m}$. Fibres nonseptate. Rays uniseriate and biseriate. Parenchyma scanty paratracheal, but predominantly as concentric bands, $2-3$ cells wide, c. 15 per $\mathrm{mm}$. Rhombic crystals abundant in the ray and parenchyma cells.
Streblus sect. Pseudostreblus (Bureau) Corner (Table 4)

A section with only one species, distributed on the Asian mainland; tall trees.

Material studied: $S$. indicus (Bureau) Corner. India: SJRw 23944 (Uw 24636).

General features: No data can be provided as only a small sectioning block was available.

Microscopic fe at ures: Vessels diffuse, solitary $(23 \%)$ and in short radial multiples and irregular clusters of $2-5 ; 15$ per sq. $\mathrm{mm}$, round to oval, diameter $110 \mu \mathrm{m}$, vessel member length $405 \mu \mathrm{m}$. Perforations simple, end walls almost transverse. Intervascular pits alternate, round, 8-9. Vessel-ray and vessel-parenchyma pits larger, elongated and irregularly shaped, halfbordered, the borders occasionally reduced. Thin-walled tyloses common. Fibres nonseptate, with small simple pits restricted to the radial walls; walls $3-4 \mu \mathrm{m}$, lumina $7-11 \mu \mathrm{m}$, often gelatinous; length $1260 \mu \mathrm{m} ; \mathrm{F} / \mathrm{V}$-ratio 3.1 . Rays uniseriate and multiseriate, heterogeneous type III, 7 per $\mathrm{mm}$. Uniseriate rays $17 \%$, composed of square, upright, and procumbent cells, height up to $7-11$ cells $(240-360 \mu \mathrm{m})$. Multiseriate rays composed of procumbent cells except for the uniseriate margins of $1-2(-4)$ 
rows of square and/or upright cells; 2 cells wide, up to $480 \mu \mathrm{m}$ high. Parenchyma (narrowly vasicentric to) aliform with long narrow wings, confluent and in wavy bands, occasionally with a tendency to unilateral paratracheal, also in some marginal bands. Parenchyma strands of 2-4 cells. Rhombic crystals few, in chambered parenchyma cells, up to 4 crystals in a longitudinal row.

\section{Streblus sect. Sloetia (Teijsm. \& Binnend.) Cor-} ner (Table 4; Figs. 39, 40)

A section with only one species, distributed in Malaya and Indonesia (Sumatra). Trees up to $35 \mathrm{~m}$ high, in lowland forests as a canopy tree, often in secondary forests, and surviving repeated coppicing.

Material studied: $S$. elongatus (Miq.) Corner. Malaysia: R 83-18, ex SFCw (Uw 24396), R 1110-78, ex SFCW (Uw 24394), DFP 12362, ex FPAw (Uw 24416), U.P.H. 373, ex RBHw (Uw 26778); Indonesia: R 575-99, ex SFCw (Uw 24395), IND. col. 713 (Uw 24444), Krukoff 4441 (Uw 25794), Krukoff 4334 (Uw 25794a).

General features: Growth rings absent or faint; heartwood dark brown and sharply defined from the light brown sapwood. Texture medium, grain straight to interlocked. Specific gravity 900-1100 N per cubic metre.

Microscopic feat ures: Vessels diffuse, solitary $(35-55 \%)$ and in short radial multiples and irregular clusters of $2-4 ; 7-14$ per sq. $\mathrm{mm}$, round to oval, diameter $100-135 \mu \mathrm{m}$, vessel member length 350-425 $\mu \mathrm{m}$. Perforations simple, end walls almost transverse. Intervascular pits alternate, round, oval to polygonal, 3-5 $\mu \mathrm{m}$. Vessel-ray and vessel-parenchyma pits larger, often elongated, irregularly shaped, half-bordered, the borders in part very reduced. Tyloses abundant, mostly thin-walled, occasionally thick-walled. Fibres nonseptate, with small simple pits restricted to the radial walls; walls 3-4 $\mu \mathrm{m}$, lumina $2-6 \mu \mathrm{m}$; length $1100-1300 \mu \mathrm{m}$; F/V-ratio 3.0-3.2. Rays uniseriate and multiseriate, heterogeneous type III, occasionally homogeneous, $5-8$ per $\mathrm{mm}$. Uniseriate rays $1-$ $17 \%$, composed of square, upright, and some procumbent cells, height up to 4-5 cells (90$180 \mu \mathrm{m}$ ). Multiseriate rays composed of procumbent cells except for the occasional uniseriate margins of 1 or 2 rows square and/or upright cells, 2-3 cells wide, up to $400-800$ $(-1200) \mu \mathrm{m}$ high. Parenchyma vasicentric, vasicentric-aliform with short wings and occasionally long wings to confluent, with a tendency to a unilateral distribution. Parenchyma strands of 3-5 cells. Rhombic crystals in the axial pa- renchyma cells, in part chambered, one crystal per chamber, up to 6 crystals in a longitudinal row, occasionally very few. Vitreous silica present in the axial parenchyma and occasionally in the fibres and/or vessels. Radial latex tubes 20-30 $\mu \mathrm{m}$ in diameter, (much) larger than the surrounding ray cells as seen in tangential section, sporadic, in three samples only.

Streblus sect. Streblus (Table 4; Figs. 41, 42)

A section with two species, distributed from Southeast Asia to China and Indonesia. Trees or shrubs up to $14 \mathrm{~m}$ high, in lowland vegetation, especially in secondary forests, and in open places.

Material studied: S. asper Lour. Philippines: Bur. Forestry 20257 (Uw 24439); Indonesia, Jaya: Koorders 1643m 11617B (Uw 24427), 136c 24871 B (Uw 24428), 136d 9545B (Uw 24429), IND. col. 1360 (Uw 26763).

General features: Growth rings absent; brown to light brown (presumably heartwood). Texture medium to coarse, grain straight. Specific gravity $500-750 \mathrm{~N}$ per cubic metre.

$M$ icroscopic feat u res: Vessels diffuse, solitary (45-60\%) and in short radial multiples and irregular clusters of 2-5;9-13 per sq. $\mathrm{mm}$, round to slightly oval, diameter $90-120 \mu \mathrm{m}$, vessel member length $310-385 \mu \mathrm{m}$. Perforations simple, end walls almost transverse. Intervascular pits alternate, round, sometimes polygonal or oval, 9-11 $\mu \mathrm{m}$. Vessel-ray and vesselparenchyma pits larger, elongated, and irregularly shaped, half-bordered, the borders often reduced. Thin-walled tyloses abundant. Fibres nonseptate, with small simple pits restricted to the radial walls; walls $2-4$, lumina $7-11 \mu \mathrm{m}$; length $985-1300 \mu \mathrm{m} ; F / V$-ratio 3.1-3.5. Rays uniseriate and multiseriate, heterogeneous type III, 6-11 per $\mathrm{mm}$. Uniseriate rays $5-7 \%$, composed of upright, square, and some procumbent cells, height up to 5-11 cells $(125-420$ $\mu \mathrm{m})$. Multiseriate rays composed of procumbent cells except for the uniseriate margins of 1-2 rows of square and/or upright cells; 3-5 cells wide, up to $370-960 \mu \mathrm{m}$ high; occasionally with some sheath cells. Parenchyma, concentric and occasionally in wavy bands, $8-12$ cells wide, 1-3 per $\mathrm{mm}$ and scanty paratracheal. $\mathrm{Pa}$ renchyma strands of 2-4 cells. Vitreous silica abundant in the vessels, and sporadically also in the fibres.

Sloetiopsis Engl. (Table 4; Figs. 43, 44)

This monotypic genus has been monographed by Berg (1977a). According to Corner (1962) Sloetiopsis might be related to his sections Sloetia and Paratrophis of the genus Streblus. 
In Berg's opinion (1977a) Sloetiopsis and the section Sloetia may prove to be congeneric, but he hesitates to include these taxa in the genus Streblus sensu Corner. The genus is distributed in Africa, from Guinea to Moçambique. Trees or shrubs up to $10 \mathrm{~m}$ high, in primary and secondary, rather humid forests, from sea level up to $1000 \mathrm{~m}$ altitude.

Mate rial st udied: $S$. usambarensis Engl. Cameroun: Leeuwenberg \& Berg 9686 (Uw 24445); Ivory Coast: Bamps 21840 (Uw 24236).

General features: Growth rings absent or faint; light yellowish brown, no demarcation between sapwood and heartwood. Texture fine, grain straight. Specific gravity $900-930 \mathrm{~N}$ per cubic metre.

Microscopic feat ures: Vessels diffuse, solitary $(60-70 \%)$ and in short radial multiples and irregular clusters of $2-4 ; 20-40$ per sq. $\mathrm{mm}$, round to oval, diameter $30-50 \mu \mathrm{m}$, vessel member length $300-350 \mu \mathrm{m}$. Perforations simple, end walls almost transverse. Intervascular pits alternate, round, or polygonal, about $2 \mu \mathrm{m}$. Vessel-ray and vessel-parenchyma pits much larger, elongated (often tending to scalariform), half-bordered, the borders very reduced to hardly visible, resulting in simple pit pairs. Thin-walled and thick-walled tyloses present. Fibres nonseptate, with small simple pits restricted to the radial walls; walls $2-4 \mu \mathrm{m}$, lumina 7-9 $\mu \mathrm{m}$, partly gelatinous; length $900-$ $1070 \mu \mathrm{m} ; \mathrm{F} / \mathrm{V}$-ratio $3.1-3.2$. Rays uniseriate and multiseriate, heterogeneous type II, 8-10 per $\mathrm{mm}$. Uniseriate rays $25-40 \%$, composed of rows of upright and square cells, occasionally one or more rows of procumbent cells, height up to 12 cells $(400 \mu \mathrm{m})$. Multiseriate rays composed of procumbent cells except for the uniseriate margins of 1-4 rows of square and/or upright cells; 3 cells wide, up to $600-720 \mu \mathrm{m}$ high; occasionally with some sheath cells. $\mathrm{Pa}$ renchyma apotracheal as narrow concentric and occasionally slightly wavy bands, one cell wide, $10-14$ bands per $\mathrm{mm}$ and occasionally also scanty paratracheal. Parenchyma strands of 3 cells. Rhombic crystals in square and upright cells, and abundant in the tyloses. The tyloses in the relatively small vessels are more or less square to angular in radial and tangential view. The crystals in these tyloses are generally larger than those in the ray cells, often several crystals in a longitudinal row. Vitreous silica present in the vessels and the tyloses, often even enveloping the crystals in the latter.

Notes. Differences in fibre wall thickness and lumen diameter produce faint growth rings. The crystals in the tyloses were erroneously interpreted by Ter Welle (1985) as chambered parenchyma cells.

\section{Trophis P. Browne}

Corner (1962) included two taxa in Trophis P. Browne, which until then had been recognised as distinct genera, viz. Calpidochlamys and Maillardia. In his treatment of the African Moraceae Berg (1977a) reduced the number of species in Maillardia to two, but retained the taxon as a distinct genus. However, he also mentioned that Corner's decision to include Maillardia in Trophis s.l. might eventually prove to be correct. According to Berg (1977a) Calpidochlamys is probably the closest relative of Maillardia. The same author accepted Trophis s.l. in 1983, but now (Berg, pers. comm.) hesitates to include both Maillardia as well as Calpidochlamys in Trophis.

The genus Olmedia was included in Trophis s.l. by Berg (1983), following his earlier statements (1977a) that considerations about the delimitation of Trophis s.l. should also include Sorocea, Olmedia, and Clarisia. Clarisia and Sorocea were assigned to the Moreae without urticaceous stamens by Berg (1983). Burger (1962) recognised the close relation between Trophis and Calpidochlamys but he did not combine them in one genus. In Burger's opinion Trophis mexicana is closely related to $T$. racemosa. Corner (1962) assigned $T$. racemosa (then $T$. americana) to his subgenus Trophis, and $T$. mexicana to a separate subgenus Prototrophis. The two subgenera, and the three sections sensu Corner (1962) will be treated here in alphabetical order, followed by the description of Olmedia.

\section{Trophis subgenus Prototrophis Corner (Table 5;}

Figs. 2, 45)

A subgenus with one species distributed in Central America. Shrubs or trees up to $20 \mathrm{~m}$ high, in moist forests, and from sea level up to $2000 \mathrm{~m}$ altitude.

Material studied: $T$. mexicana (Liebm.) Bureau. Guatemala: Sosa 50 (Uw 18029).

General feat ures: Growth rings absent; heartwood brown, sapwood yellow. Texture medium, grain straight. Specific gravity $800 \mathrm{~N}$ per cubic metre.

Microscopic fe a tures: Vessels diffuse, solitary $(20 \%)$ and in short radial multiples and irregular clusters of $3-6 ; 8$ per sq. $\mathrm{mm}$, round to oval, occasionally angular, diameter $145 \mu \mathrm{m}$, vessel member length $370 \mu \mathrm{m}$. Perforations simple, end walls almost transverse to slightly oblique. Intervascular pits alternate, round or polygonal, $9 \mu \mathrm{m}$. Vessel-ray and vessel-parenchyma pits larger, elongated and irregularly shaped, half-bordered, the borders sometimes reduced. Thin-walled tyloses present. Fibres nonseptate, with small simple pits restricted to 


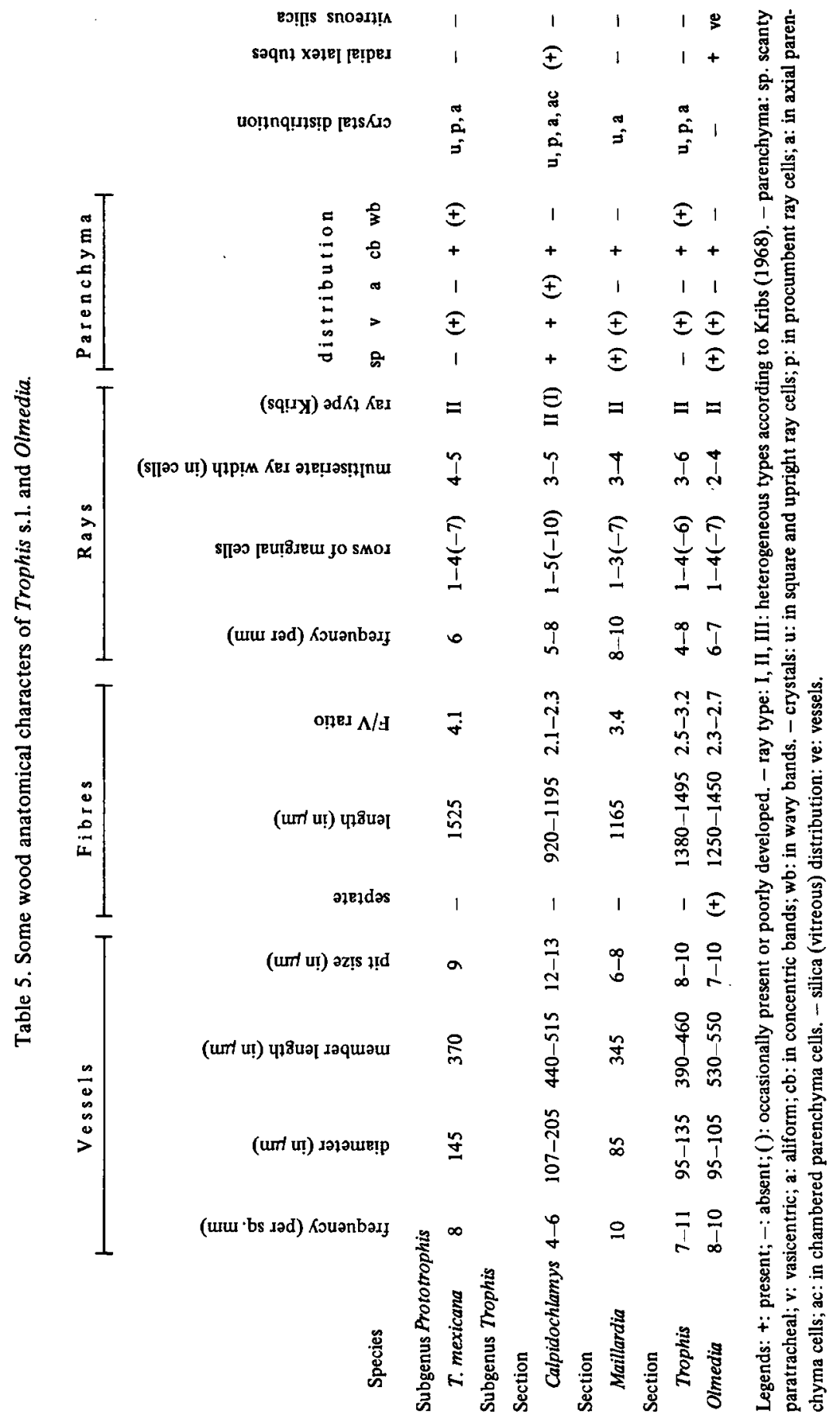


the radial walls; walls $4 \mu \mathrm{m}$, lumina $7 \mu \mathrm{m}$, occasionally gelatinous; length $1525 \mu \mathrm{m} ; \mathrm{F} / \mathrm{V}$-ratio 4.1. Rays uniseriate and multiseriate, heterogeneous type II, 6 per $\mathrm{mm}$. Uniseriate rays 20 $\%$, composed of square and upright and some procumbent cells, height up to 6 cells $(240$ $\mu \mathrm{m})$. Multiseriate rays composed of procumbent cells except for the uniseriate margins of $1-4(-7)$ rows of square and/or upright cells; $4-5$ cells wide, up to $960 \mu \mathrm{m}$ high. Parenchyma vasicentric and predominantly as concentric, slightly wavy bands, 3-6(-9) cells wide, 2-3 bands per $\mathrm{mm}$. Parenchyma strands of 3-5 cells. Rhombic crystals abundant in the rays, present in nearly all square and upright cells, also in some procumbent ray cells, and very common in the axial parenchyma cells.

Trophis subgenus Trophis sect. Calpidochlamys (Diels) Corner (Table 5; Figs. 2, 48, 49)

The section comprises three species, distributed in Malaysia, Philippines and Indonesia. Trees up to $30 \mathrm{~m}$ high in primary and secondary forests, in the lowlands and up to $1500 \mathrm{~m}$ altitude.

Material studied: T. philippinensis (Bureau) Corner. Indonesia, Irian Jaya: BW 11922 (Uw 18173), Fokkinga 1871 (Uw 24355).

General features: Growth rings absent; heartwood brown to dark brown, not well defined from the golden yellow sapwood. Texture coarse, grain straight. Specific gravity $530-600 \mathrm{~N}$ per cubic metre.

Micr os copic fe a tures: Vessels diffuse, solitary (35-69\%) and in short radial multiples and/or irregular clusters of 2-4;4-6 per sq. mm, round to oval, diameter 170-205 $\mu \mathrm{m}$, vessel member length 440-515 $\mu \mathrm{m}$. Perforations simple, end walls almost transverse. Intervascular pits alternate, round, oval or polygonal, 12-13 $\mu \mathrm{m}$. Vessel-ray and vessel-parenchyma pits larger, elongated and irregularly shaped, half-bordered, the borders occasionally very reduced. Thin-walled tyloses present. Fibres nonseptate, with small simple pits restricted to the radial walls; walls $2-4 \mu \mathrm{m}$, lumina $16-20$ $\mu \mathrm{m}$; length 920-1195 $\mu \mathrm{m} ; \mathrm{F} / \mathrm{V}$-ratio 2.1-2.3. Rays uniseriate and multiseriate, heterogeneous type II (I), 5-8 per $\mathrm{mm}$. Uniseriate rays $15-25$ $\%$, composed of square, upright and some procumbent cells, height up to $10-15$ cells (240$480 \mu \mathrm{m})$. Multiseriate rays composed of procumbent cells except for the uniseriate margins of $1-5(-10)$ rows of square and/or upright cells; $3-5$ cells wide, up to $840-1200 \mu \mathrm{m}$ high; occasionally with some sheath cells. Parenchyma scanty paratracheal to vasicentric (one cell wide), to slightly aliform with minimal wings, and in bands, $3-5$ cells wide, $0.1-1$ per $\mathrm{mm}$.
Parenchyma strands of 4 cells. Rhombic crystals abundant in the rays, in nearly all square and upright cells (in some upright cells more than one crystal), less frequent in the procumbent cells, and very common in the axial parenchyma cells, the cells often chambered, up to 4-10 crystals in longitudinal rows. Radial latex tubes few, diameter 25-50 $\mu \mathrm{m}$, much larger than the surrounding ray cells as seen in tangential section, in one sample.

Trophis subgenus Trophis sect.Maillardia (Frappier \& Duchartre) Corner (Table 5; Figs. 2, 50,51 )

This section comprises two closely related species of trees up to $15 \mathrm{~m}$ tall (Berg, 1977a), distributed in Madagascar, Réunion, and Aldabra and the Comoro Islands, and is found in dry and wet forests, from sea level up to 1500 $m$ altitude.

Material studied: 'Maillardia borboni$\mathrm{ca}^{\prime}$ (this name is used as Corner did not publish a new combination in accordance with the stat. nov. of Maillardia in Trophis). Réunion: T. Cadet 6310 (Uw 27392).

General feat ures: Growth rings absent; sapwood white to yellow. Texture fine, grain straight. Specific gravity $840 \mathrm{~N}$ per cubic metre.

Microscopic feat ures: Vessels diffuse, solitary $(40 \%)$ and in short radial multiples and irregular clusters of $2-5 ; 10$ per sq. $\mathrm{mm}$, round to oval, diameter $85 \mu \mathrm{m}$, vessel member length $345 \mu \mathrm{m}$. Perforations simple, end walls almost transverse. Intervascular pits alternate, round, oval or polygonal, 6-8 $\mu \mathrm{m}$. Vessel-ray and vessel-parenchyma pits larger, elongated and irregularly shaped, half-bordered, the borders occasionally reduced. Fibres nonseptate, with small simple pits restricted to the radial walls; walls 2-4 $\mu \mathrm{m}$, lumina 7-11 $\mu \mathrm{m}$, occasionally gelatinous; length $1165 \mu \mathrm{m} ; \mathrm{F} / \mathrm{V}$-ratio 3.4. Rays uniseriate and multiseriate, heterogeneous type II, $8-10$ per $\mathrm{mm}$. Uniseriate rays $50 \%$, composed of upright cells, and few procumbent cells, height up to 13 cells $(480 \mu \mathrm{m})$. Multiseriate rays composed of procumbent cells except for the uniseriate margins of $1-3(-7)$ rows of square and/or upright cells; 3-4 cells wide, up to $720 \mu \mathrm{m}$ high. Parenchyma scanty paratracheal, only occasionally completely vasicentric, predominantly in narrow regular concentric 2-5 cells wide bands, 4-6 bands per $\mathrm{mm}$. Parenchyma strands of 4 cells. Rhombic crystals present, scattered in square and upright ray cells, less frequent in the axial parenchyma cells.

Note: The high value for the percentage of uniseriate rays might be due to the limited diameter of the sample. 
Trophis subgenus Trophis sect. Trophis (Table 5; Figs. 2, 46, 47)

The single species $T$. racemosa occurs from Central America and the West Indies to Colombia and Peru. Trees up to $18 \mathrm{~m}$ high, in humid forests, from sea level up to $1000(-2500) \mathrm{m}$ altitude.

Material studied: $T$. racemosa (L.) Urb. Mexico, Los Tuxtlas: R. C. Trigos 306 (Uw 25690); Honduras: Record \& Kuylen 40 (Uw 26145); Venezuela, Mérida: Breteler 4573 (Uw 12205); Peru: ex FPAw 25331 (Uw 24365).

General features: Growth rings absent; heartwood brown, sapwood yellow. Texture medium, grain interlocked. Specific gravity $700-850 \mathrm{~N}$ per cubic metre.

Microscopic features: Vessels diffuse, solitary (20-50\%) and in short radial multiples and irregular clusters of 3-6;7-11 per sq. $\mathrm{mm}$, round to oval, occasionally angular, diameter 95-135 $\mu \mathrm{m}$, vessel member length 390-460 $\mu \mathrm{m}$. Perforations simple, end walls almost transverse to slightly oblique. Intervascular pits alternate, round to polygonal, 8-10 $\mathrm{mm}$. Vesselray and vessel-parenchyma pits larger, elongated, and irregularly shaped, half-bordered, the borders sometimes reduced. Thin-walled tyloses common. Fibres nonseptate, with small simple pits restricted to the radial walls; walls 2-4 $\mu \mathrm{m}$, lumina 4-9 $\mu \mathrm{m}$, occasionally gelatinous, length 1380-1495 $\mu \mathrm{m} ; \mathrm{F} / \mathrm{V}$-ratio 2.5-3.2. Rays uniseriate and multiseriate, heterogeneous type II, 4-8 per mm. Uniseriate rays 5-30\%, composed of square, upright and few procumbent cells, height up to $8-12$ cells $(360-420$ $\mu \mathrm{m})$. Multiseriate rays composed of procumbent cells except for the uniseriate margins of $1-4(-6)$ rows of square and/or upright cells; 3-6 cells wide, up to $840-1320 \mu \mathrm{m}$ high. $\mathrm{Pa}$ renchyma in complete vasicentric rings, and predominantly as concentric, 3-6 cells wide, slightly wavy bands, 4-5 bands per $\mathrm{mm}$, and some 1 cell wide marginal bands. Parenchyma strands of 3-8 cells. Rhombic crystals mostly abundant in the rays, in nearly all square and upright cells, also in procumbent ray cells, and very common in the axial parenchyma.

Note: $T$. racemosa from Venezuela has much less abundant rhombic crystals in the ray and parenchyma cells than the other samples.

Olmedia Ruiz \& Pavon (Table 5; Figs. 52-54)

A monograph of Olmedia was published by Berg (1972). He assigned only one species to this genus. More recently the same author (1983) included the genus in Trophis s.l., however without making new combinations. The genus Olmedia is distributed from Costa Rica through the Andes to Bolivia. Trees or shrubs up to $20 \mathrm{~m}$ high, in humid forests, up to 1500 $m$ altitude.

Material studied: $O$. aspera Ruiz \& Pavon. Panama: Dressler 5196 (Uw 21743); Ecuador: Maas, Berg \& ter Welle 2954 (Uw 23576), Berg \& Akkermans 1047 (Uw 27038); Peru: Williams 7082 (Uw 18429), 6019 (Uw 18430).

General features: Growth rings absent; whitish yellow, no demarcation between sapwood and heartwood. Texture medium, grain straight. Specific gravity $550-700 \mathrm{~N}$ per cubic metre.

$\mathrm{Microscopic}$ features: Vessels diffuse, solitary $(50-70 \%)$ and in radial multiples and irregular clusters of $2-4 ; 8-10$ per sq. $\mathrm{mm}$, round to oval, diameter 95-105 $\mu \mathrm{m}$, vessel member length 530-550 $\mu \mathrm{m}$. Perforations simple, end walls slightly oblique to almost transverse. Intervascular pits alternate, round, oval and polygonal, 7-10 $\mu \mathrm{m}$. Vessel-ray and vesselparenchyma pits larger, often elongated and irregularly shaped, half-bordered, the borders very reduced. Thin-walled tyloses common. Fibres septate, or septate and nonseptate in the same sample, with small simple pits restricted to the radial walls; walls $2-3 \mu \mathrm{m}$, lumina $12-$ $20 \mu \mathrm{m}$; of ten gelatinous; length 1250-1450 $\mu \mathrm{m} ; \mathrm{F} / \mathrm{V}$-ratio $2.3-2.7$. Rays uniseriate and multiseriate, heterogeneous type II, 6-7 per $\mathrm{mm}$. Uniseriate rays $5-20 \%$, composed of square, upright and few procumbent cells, height up to 5-9 cells $(240-360 \mu \mathrm{m})$. Multiseriate rays composed of procumbent cells except for the uniseriate margins of $1-4(-7)$ rows of square and/or upright cells, 2-4 cells wide, height up to $840-1320 \mu \mathrm{m}$. Sheath cells common. Parenchyma scanty paratracheal, only occasionally vasicentric as a complete ring of one cell wide, predominantly as more or less regular concentric bands, 3-12 cells wide, $2-4$ bands per $\mathrm{mm}$, often including the vessels. Parenchyma strands of 3-4 cells. Vitreous silica common in the vessels. Radial latex tubes present, infrequent, diameter $10-15 \mu \mathrm{m}$, equal to the diameter of the surrounding ray cells as seen in tangential section.

Note: Mennega and Lanzing-Vinkenborg (1977) described Olmedia as having nonseptate fibres (exceptionally one or two septate fibres seen in macerations). However, in two samples collected more recently in Ecuador, the fibres are definitively septate. Preparation of additional sections of the material studied by Mennega and Lanzing-Vinkenborg revealed the presence of septate fibres in these samples too, although the majority of the fibres is nonseptate.

(text continued on page 124) 

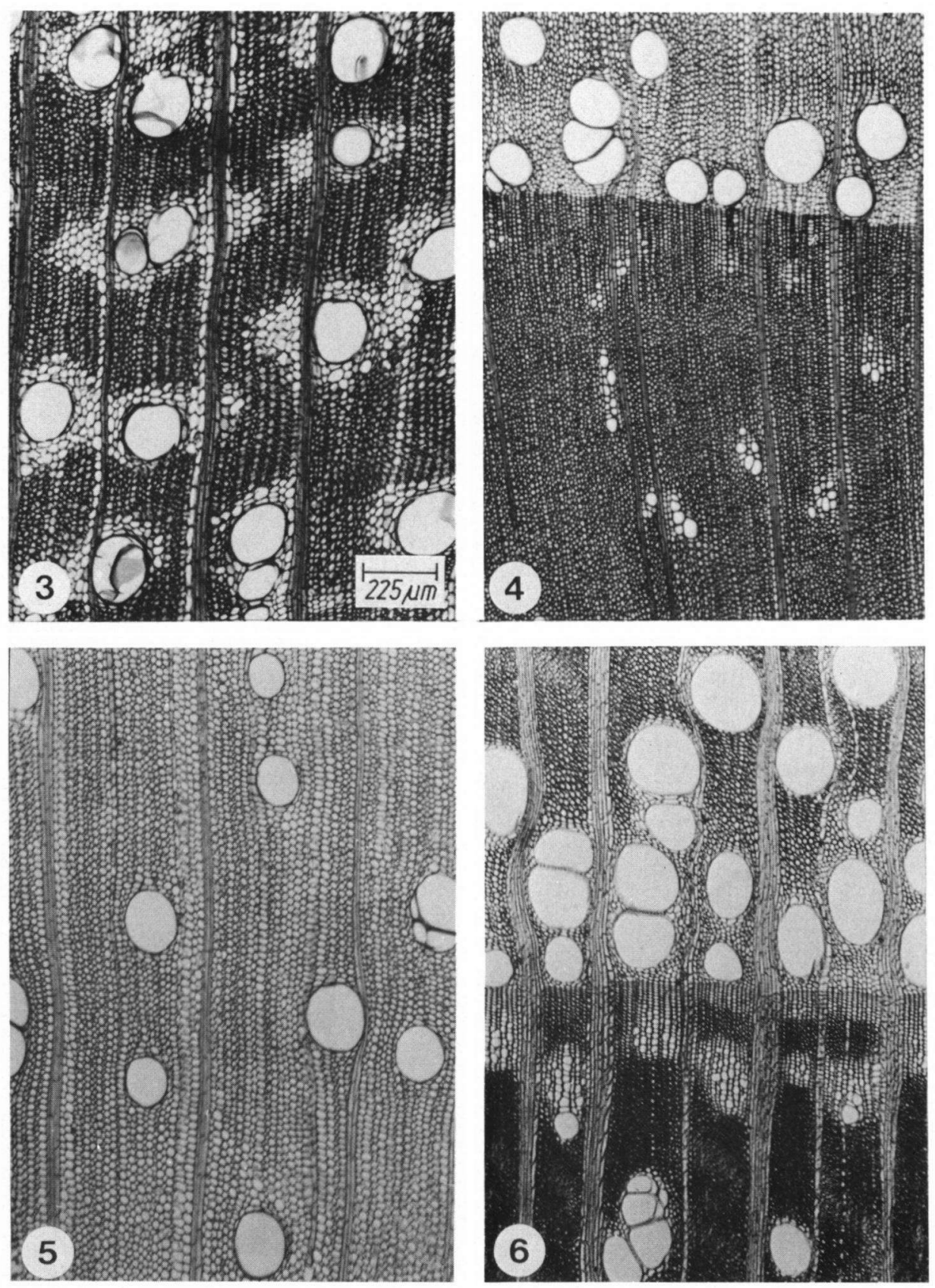

Fig. 3. Broussonetia sect. Allaeanthus, B. greveana, Uw 26758, Madagascar. Scale line valid for all photomicrographs, unless otherwise indicated. - Fig. 4. Broussonetia sect. Broussonetia, B. kazinoki, Uw 26765, Japan. - Fig. 5. Ibid., B. papyrifera, Uw 24338, Thailand. - Fig. 6. Ibid., ibid., UNw 213, the Netherlands. 

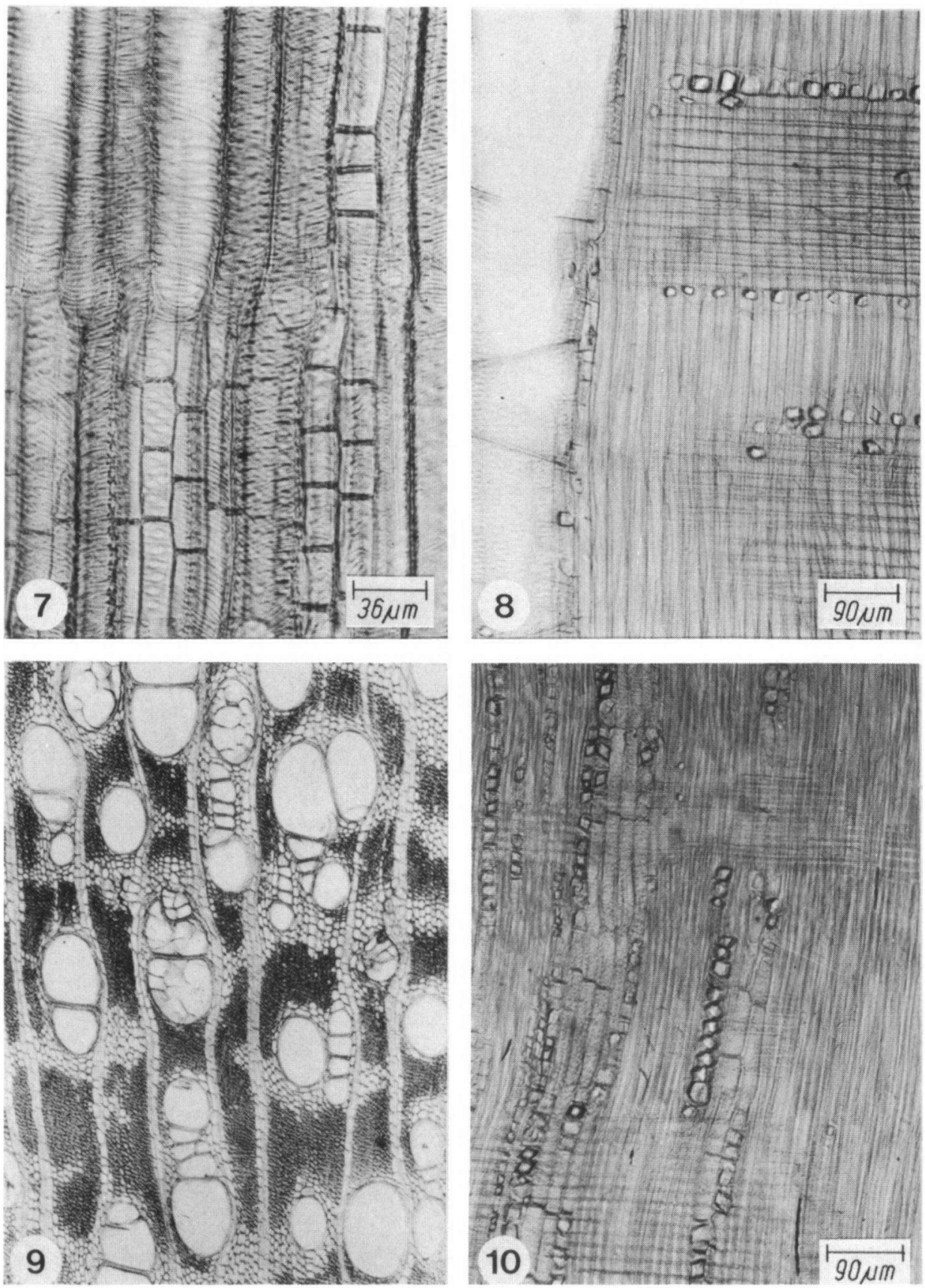

Fig. 7. Broussonetia sect. Broussonetia, B. kazinoki, Uw 26979. - Fig. 8. Ibid., B. papyrifera, Uw 24338. - Fig. 9. Maclura sect. Cardiogyne, M. africana, Uw 27394. - Fig. 10. Maclura sect. Chlorophora, M. tinctoria, Uw 25792. 

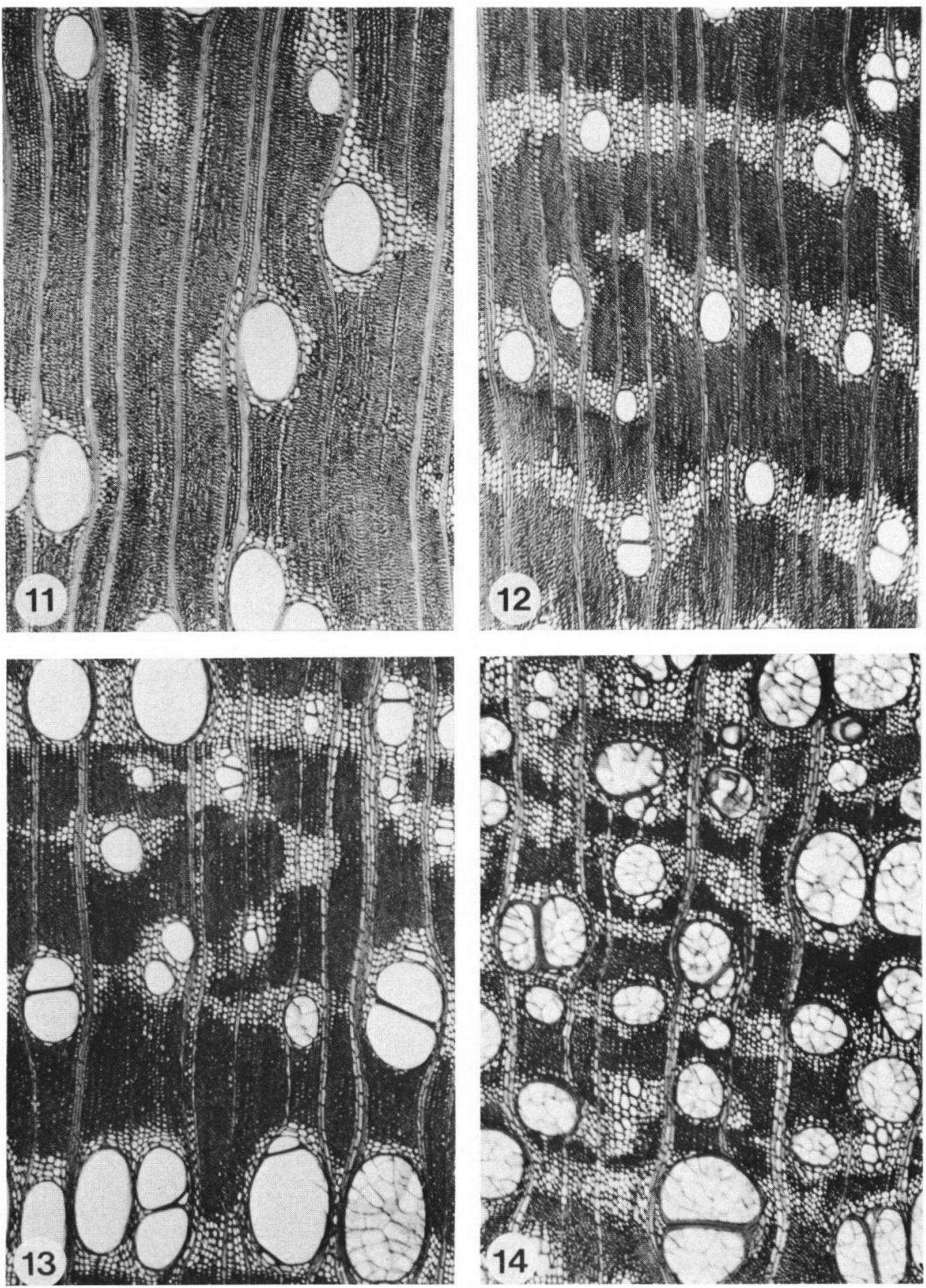

Fig. 11. Maclura sect. Chlorophora, M. tinctoria, Uw 25792, Mexico. - Fig. 12. Ibid., ibid., Uw 18419, Venezuela. - Fig. 13. Maclura sect. Cudrania, M. cochinchinensis, Uw 18521, Australia. Fig. 14. Ibid., ibid., Uw 25798, Indonesia. 

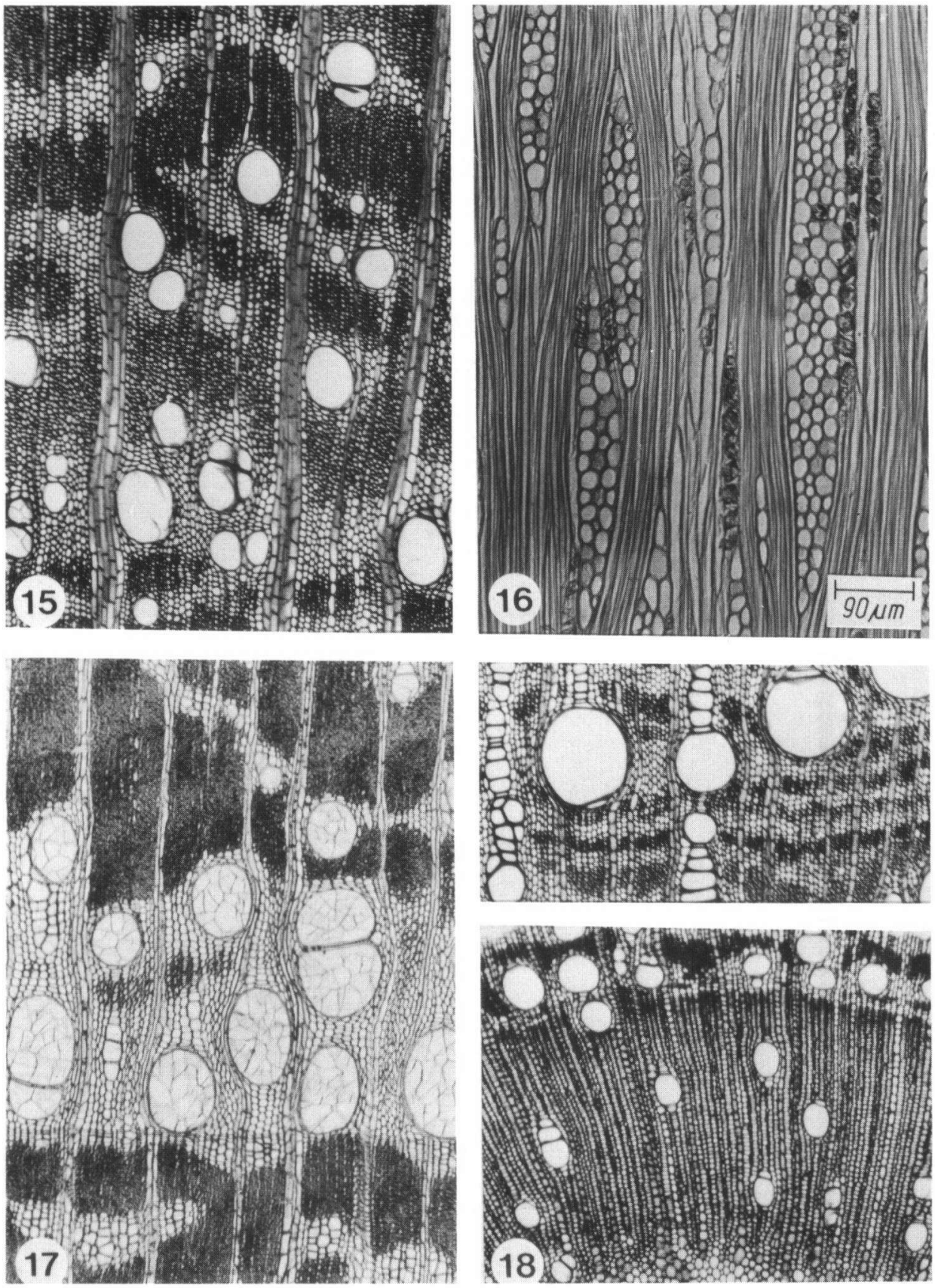

Fig. 15. Maclura sect. Cudrania, M. tricuspidata, Uw 18397, U.K., cult. - Fig. 16. Ibid., M. cochinchinensis, Uw 18396. - Fig. 17. Maclura sect. Maclura, M. pomifera, Uw 7227, U.S.A. - Fig. 18. Ibid., M. brasiliensis, Uw 26767 (upper part; stem periphery; lower part: juvenile wood near pith). 

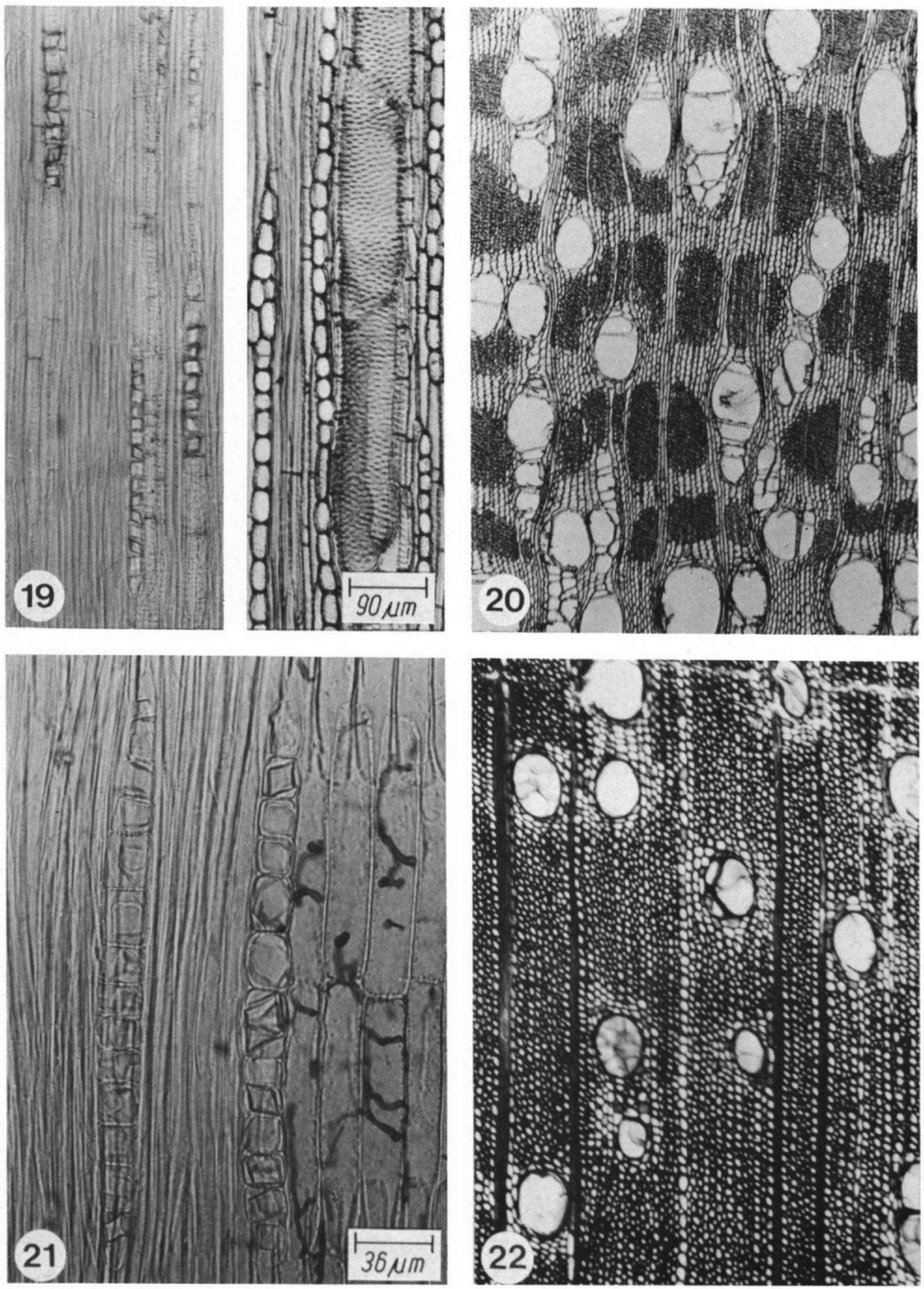

Fig. 19. Maclura sect. Maclura, M. brasiliensis, Uw 26767; rhombic crystals in chambered parenchy. ma cells (left), rays and vessel (right). - Fig. 20. Plecospermum spinosum, Uw 18400. - Fig. 21 Ibid., Uw 18400. - Fig. 22. Malaisia scandens, Uw 24362. 

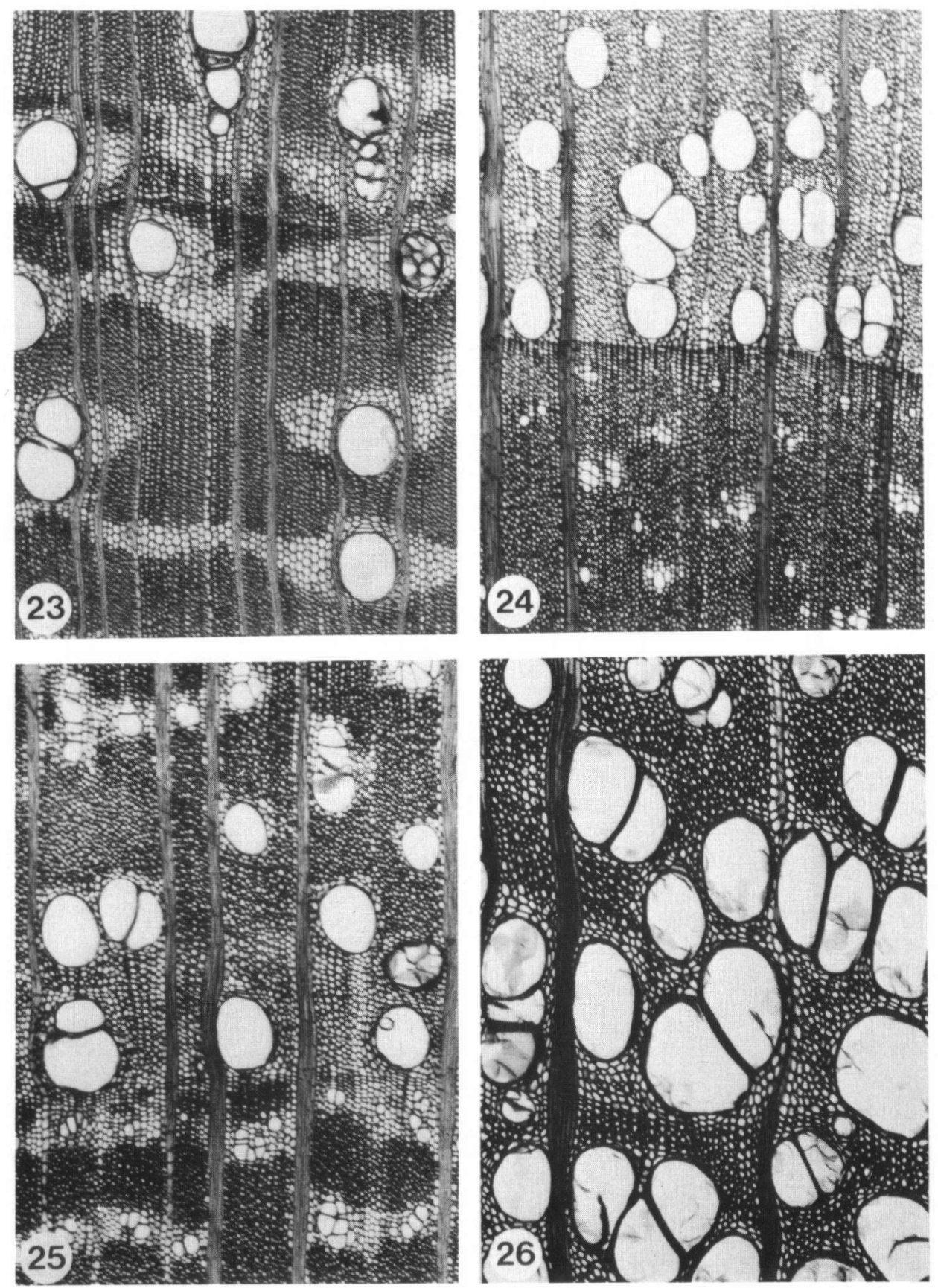

Fig. 23. Milicia excelsa, Uw 15648. - Fig. 24. Morus alba, Uw 309, the Netherlands. - Fig. 25 Ibid., Uw 25505, South Africa. - Fig. 26. Ibid., Uw 25787, India, Himalaya. 

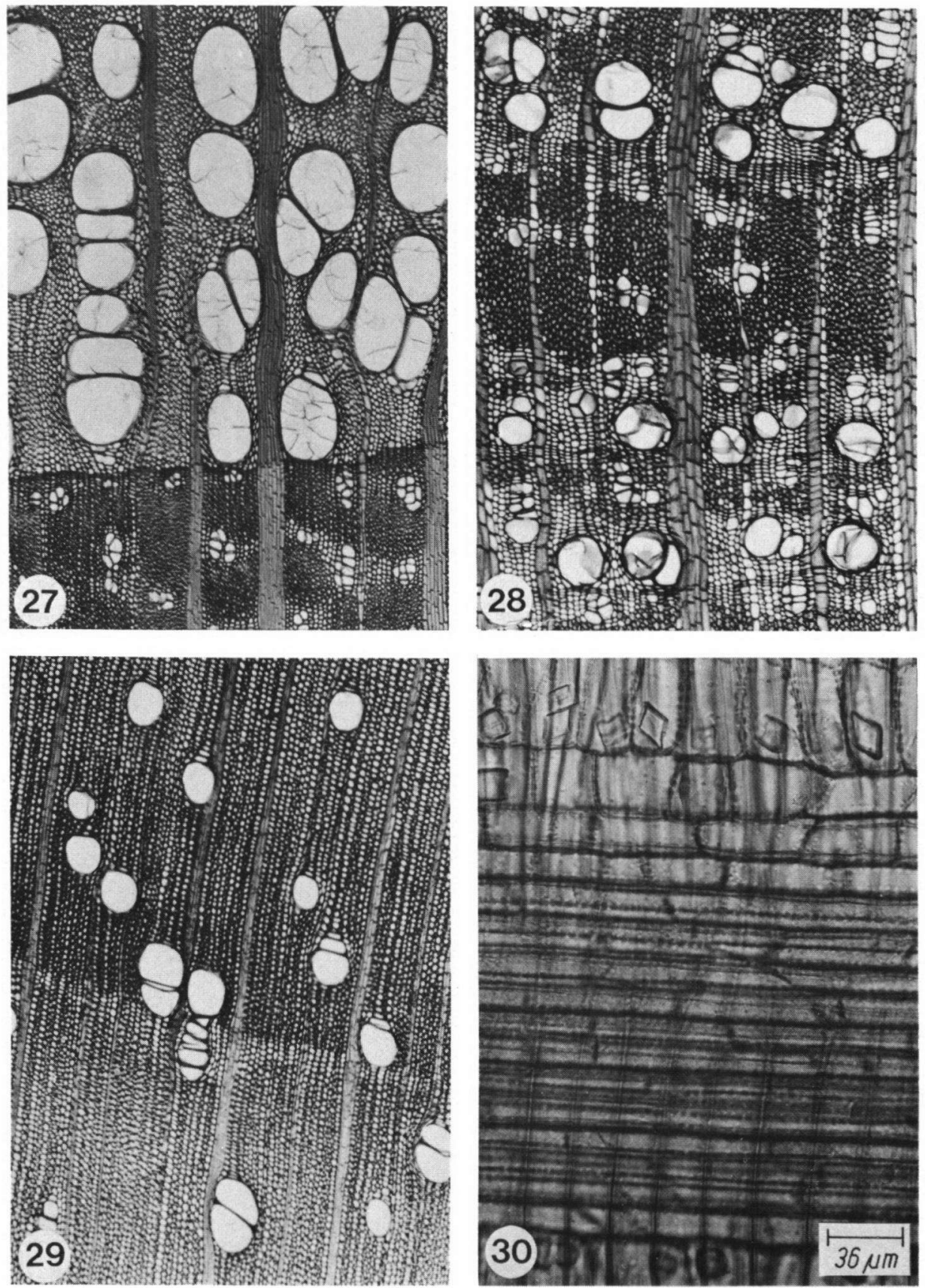

Fig. 27. Morus rubra, Uw 7336, U.S.A. - Fig. 28. Morus nigra, Uw 25788, Lebanon. - Fig. 29. Morus insignis, Uw 24976, Colombia, Andes. - Fig. 30. Ibid., Uw 24976. 

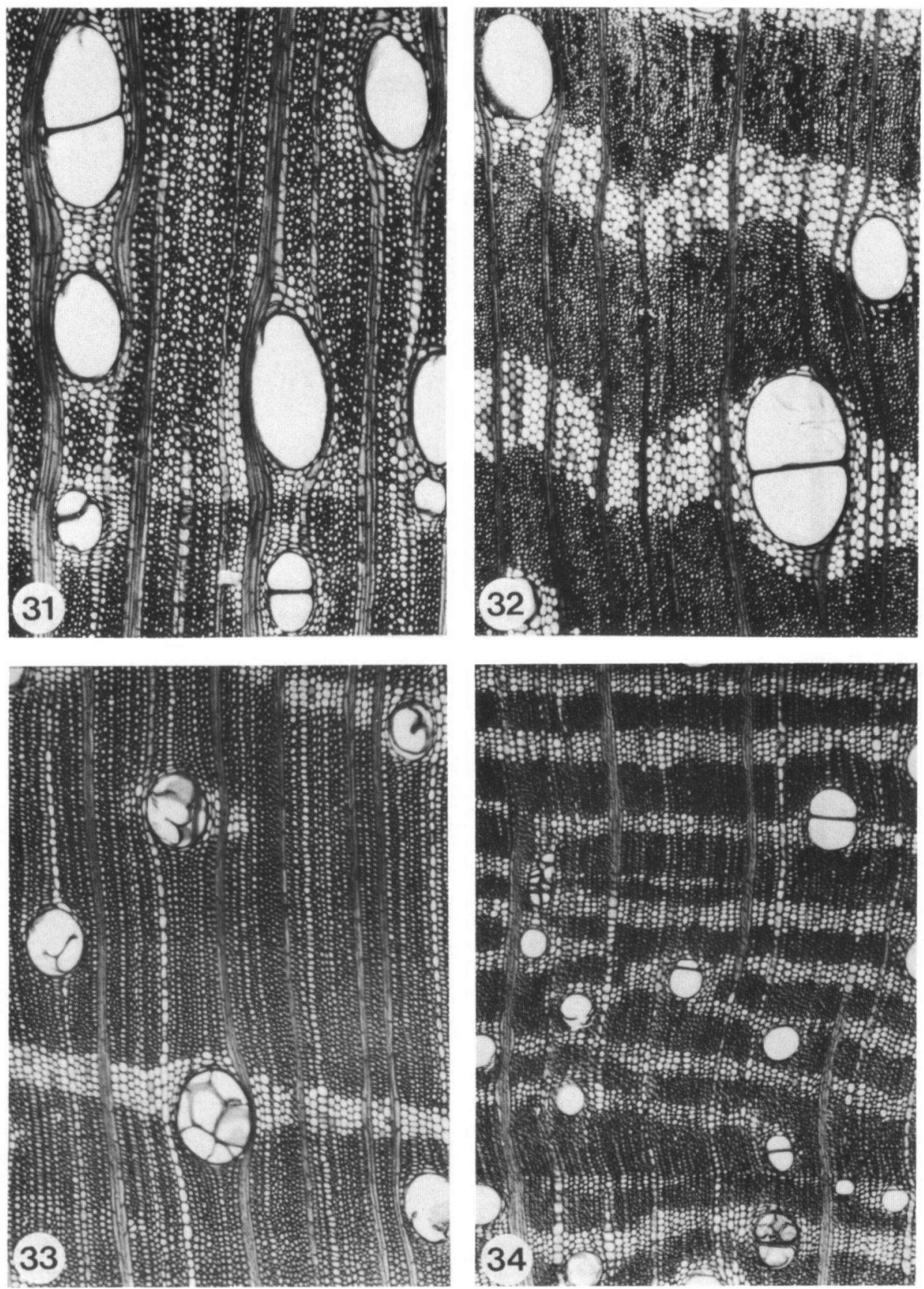

Fig. 31. Morus macroura, Uw 24426, Java. - Fig. 32. Morus mesozygia, Uw 18399, Nigeria. - Fig 33. Pachytrophe dimepate, Uw 24257. - Fig. 34. Ibid., Uw 26144. 

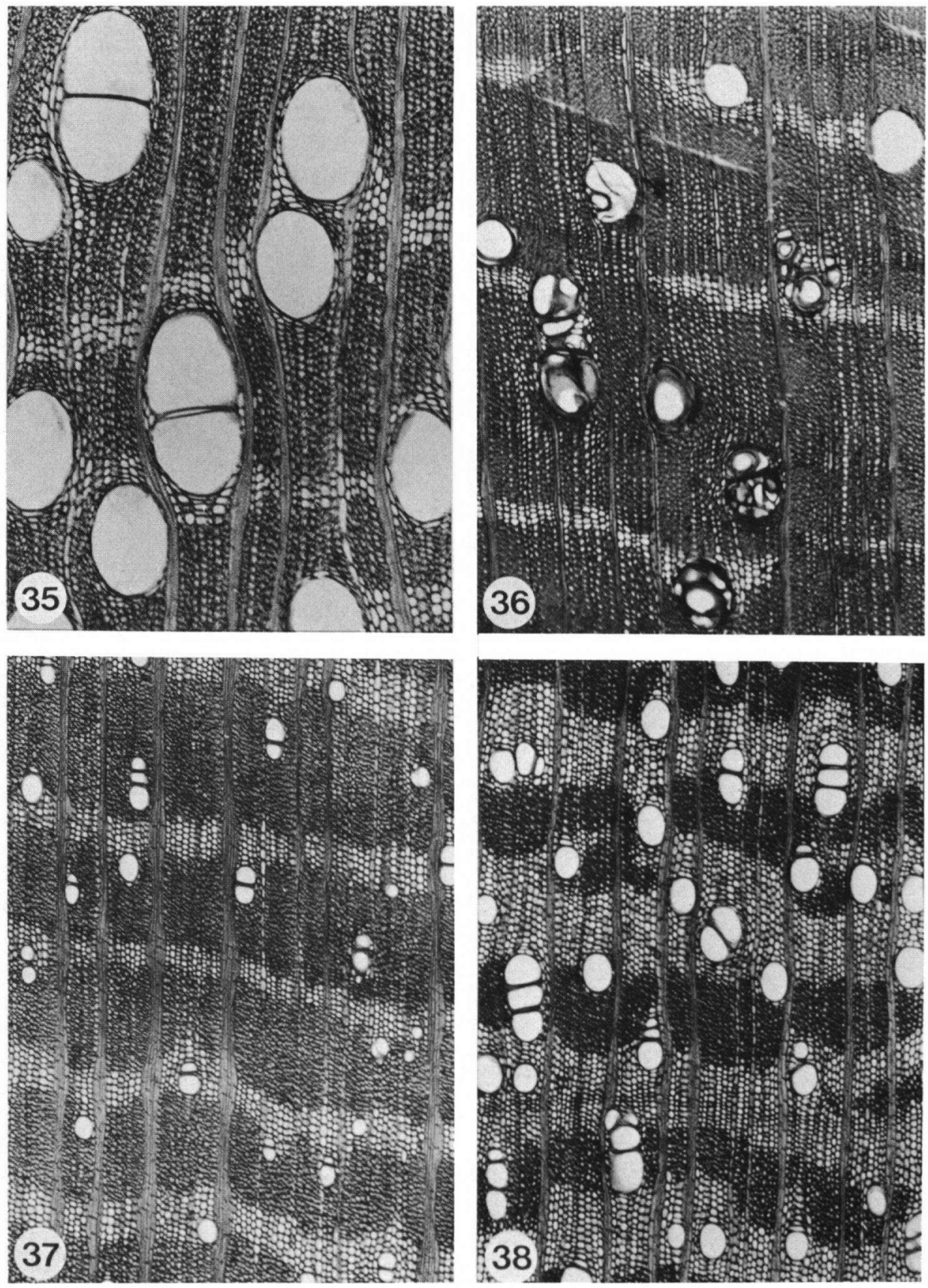

Fig. 35. Streblus sect. Paratrophis, S. glaber, Uw 20480. - Fig. 36. Ibid., ibid., Uw 24237. - Fig. 37. Ibid., S. pendulinus, Uw 24387. - Fig. 38. Ibid., ibid., Uw 24388. 

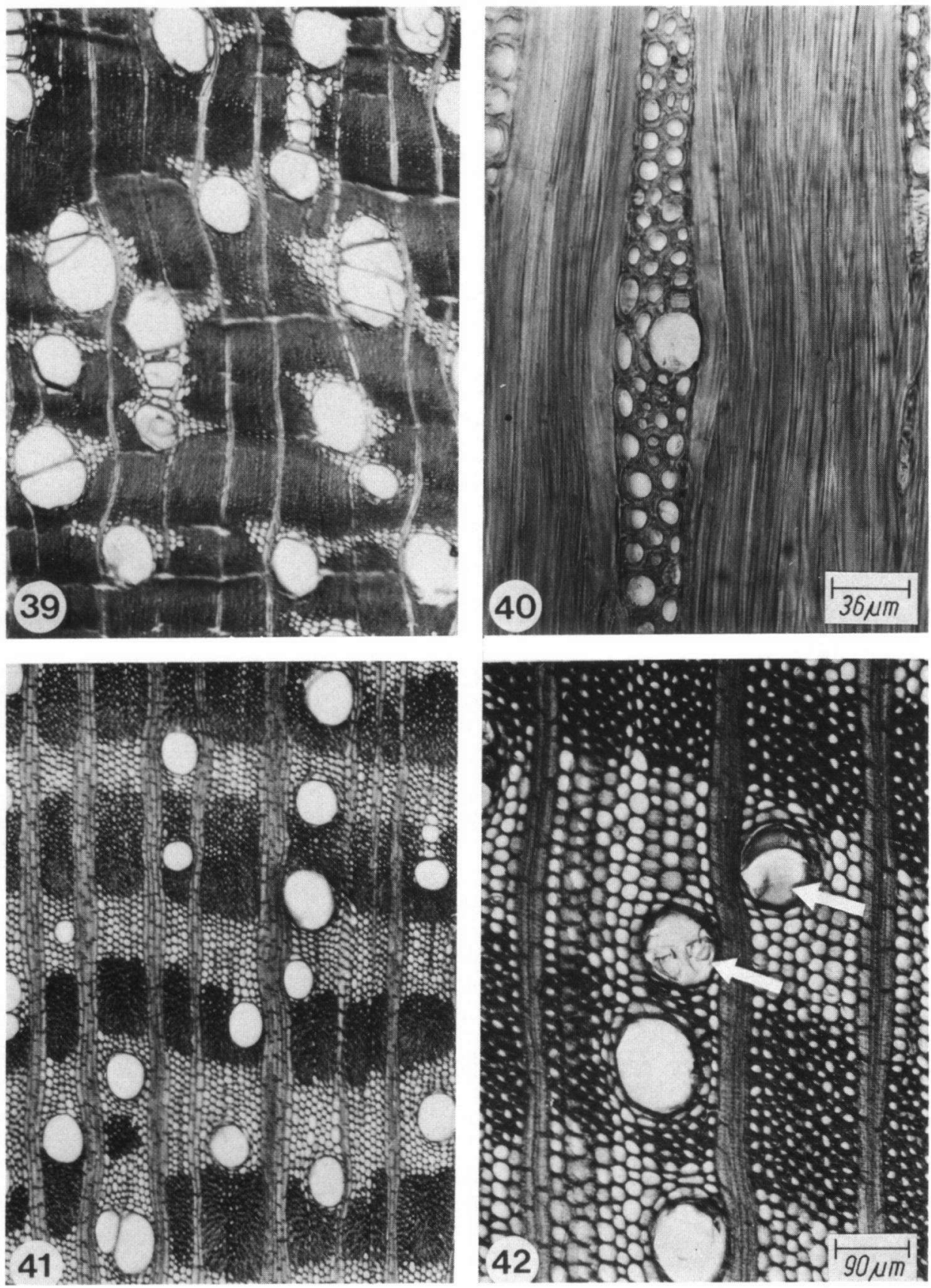

Fig. 39. Streblus sect. Sloetia, S. elongatus, Uw 24396. - Fig. 40. Ibid., ibid., Uw 24396: laticifer in ray. - Fig. 41. Streblus sect. Streblus, S. asper, Uw 24428. - Fig. 42. Ibid., ibid., Uw 24439: silica in the vessels arrowed. 

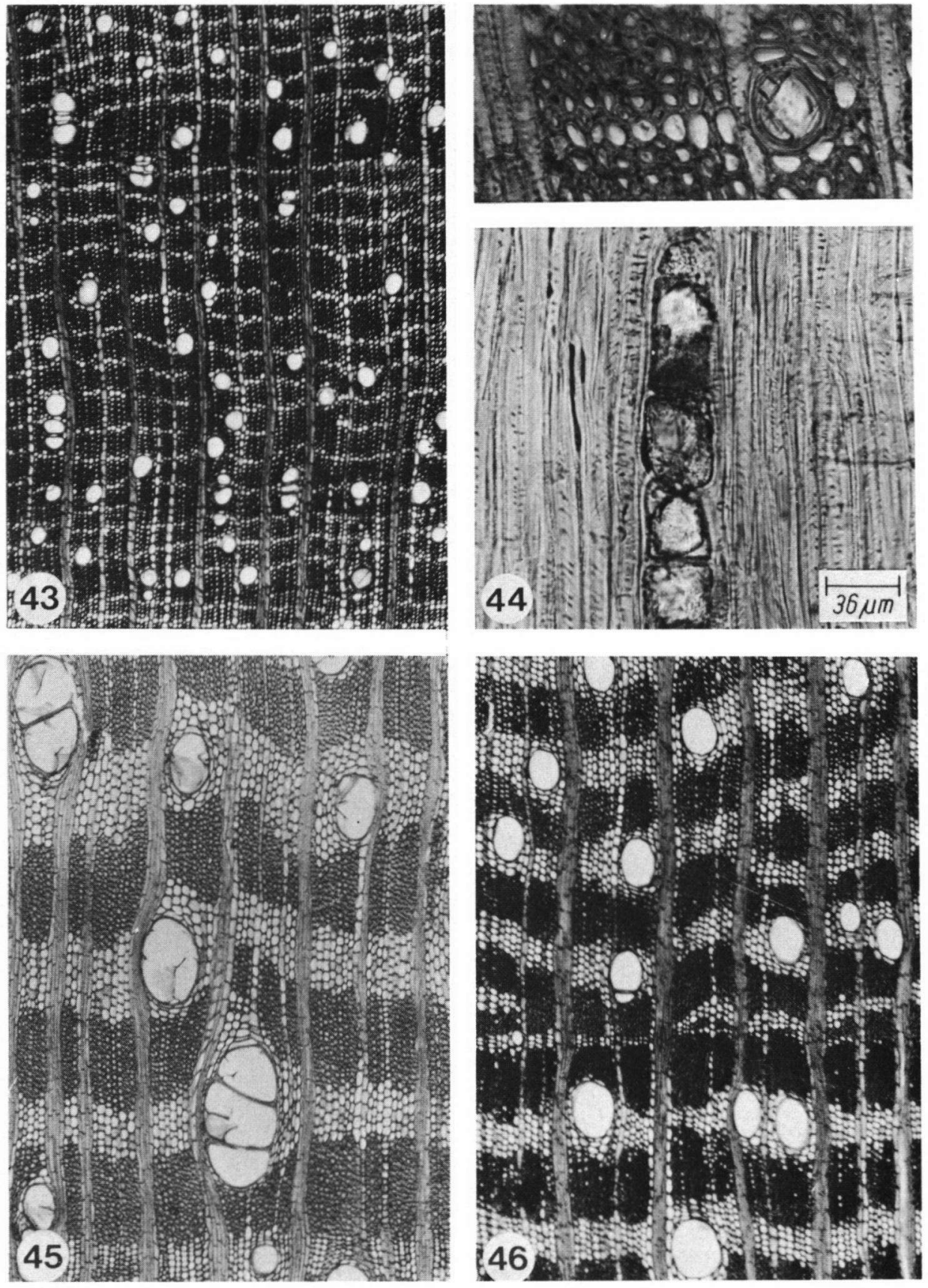

Fig. 43. Sloetiopsis usambarensis, Uw 24445. - Fig. 44. Ibid., Uw 24236: crystals in the tyloses of the vessels, in transverse and tangential section. - Fig. 45. Trophis subg. Prototrophis, T. mexicana, Uw 18029. - Fig. 46. Trophis subg. Trophis sect. Trophis, T. racemosa, Uw 25690. 

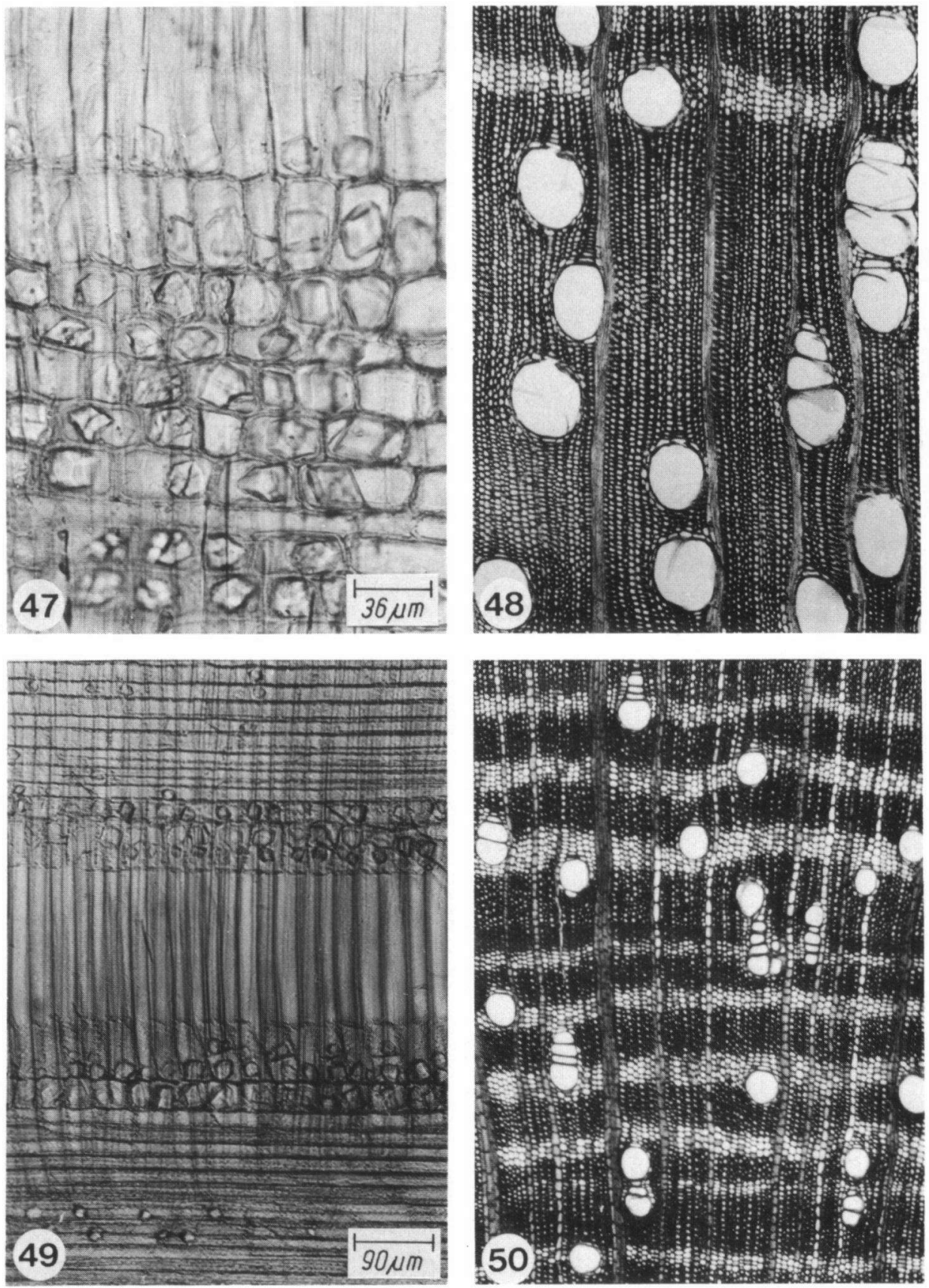

Fig. 47. Trophis subg. Trophis sect. Trophis, T. racemosa, Uw 25690. - Fig. 48. Ibid. sect. Calpidochlamys, T. philippinensis, Uw 18173. - Fig. 49. Ibid., ibid., Uw 18173. - Fig. 50. Trophis subg. Trophis sect. Maillardia, T. borbonica, Uw 27392. 

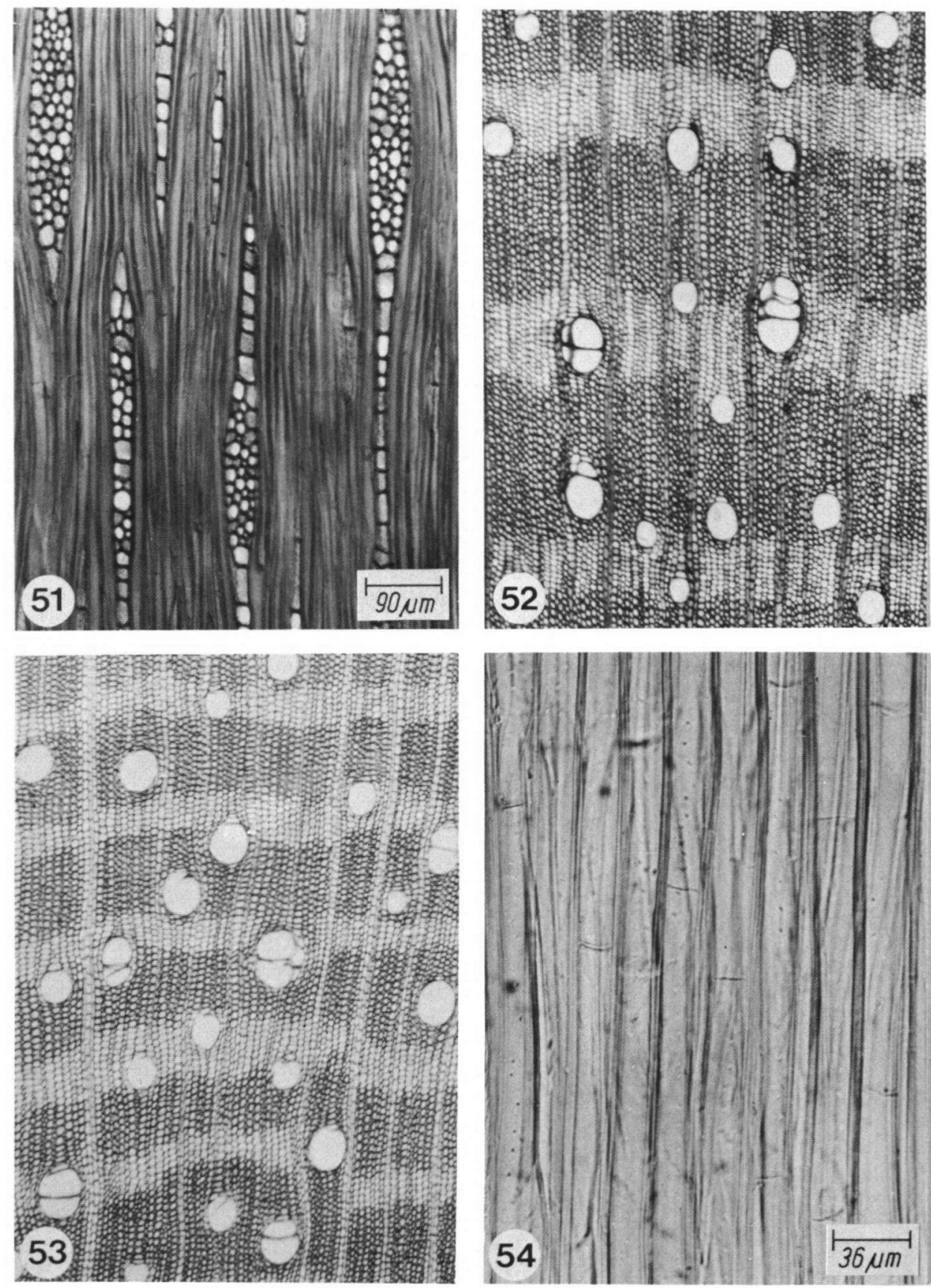

Fig. 51. Trophis subg. Trophis sect. Maillardia, T. borbonica, Uw 27392. - Fig. 52. Olmedia aspera, Uw 23576. - Fig. 53. Ibid., Uw 21743. - Fig. 54. Ibid., Uw 23576: septate fibres. 


\section{Discussion}

\section{Ecology and wood anatomy}

The majority of the taxa of Moreae sensu Berg with urticaceous stamens is distributed in tropical lowland vegetations with moderate to abundant water supplies. However, Morus. Broussonetia and Maclura are represented in tropical and temperate areas; Plecospermum is found in rather dry habitats of India and Sri Lanka, and the two species of Streblus sect. Paratrophis occur in tropical lowland and tropical montane forests, respectively.

Broussonetia - Species of Broussonetia are found in temperate and tropical areas of Asia and Madagascar. The section Allaeanthus (3 species) is tropical; the section Broussonetia (4 species) is mainly temperate. Only $B$. papyrifera occurs in the tropics, as well as in temperate areas. As can be seen in Table 1 and Fig. 1, in general the element length in the temperate species is shorter than in the tropical species, and the vessel diameter is slightly smaller in the temperate species, thus confirming the trends established by Van der Graaff and Baas (1974). However, for both trends exceptions exist in our material.

The most striking difference is found in the porosity patterns: ring-porous in the temperate species, and diffuse-porous in the tropical species, with the exception of one sample of $B$. papyrifera from Indonesia which shows a semiring-porous vessel distribution. As no information on habitat of this sample is available, this cannot be explained.

Spiral thickenings occur in the smaller vessels of all samples with a ring-porous vessel distribution, and also in the diffuse-porous sample of $B$. papyrifera from Thailand. Thus spiral thickenings occur in all samples of the section Broussonetia, and never in those of the section Allaeanthus. Spiral thickenings are commonly regarded as an ecological adaptation and are therefore not considered as a taxonomic criterion. In Broussonetia, however, it seems possible to recognise both sections with the aid of this feature.

The parenchyma distribution is strongly dominated by the vessel distribution. In ringporous samples the parenchyma is scanty paratracheal with terminal or initial bands, and in diffuse-porous samples aliform-confluent, and sometimes with short bands. Broussonetia kurzii from Thailand shows only vasicentric parenchyma.

Maclura - As can be seen in Table 2, in Maclura again ring-porosity and spiral thicken- ings distinguish the temperate and subtropical from the tropical species. Element lengths of tropical species are higher than those of temperate species.

Morus - The species and samples available for this study are from temperate, tropical lowland and tropical montane vegetations. For wood anatomical data per species, see Table 3 and Figure 1.

The vessel member length in the tropical specimens is slightly higher and the fibre length considerably higher than in temperate species. Within the tropical specimens the vessel member length is slightly lower in the montane taxa. Morus nigra, with a natural distribution in the dry eastern, Mediterranean (subtropical) areas, falls within the range of the tropical taxa. The samples studied are from Lebanon and the Netherlands.

A ring-porous vessel distribution is observed in the specimens from temperate areas. Here, also spiral thickenings occur. The tropical lowland species, $M$. mesozygia, is diffuse-porous and lacks spiral thickenings. Morus macroura, from tropical montane areas, is semi-ring-porous with faint spiral thickenings. However, $M$. insignis is diffuse-porous and lacks spiral thickenings, although it is a tropical montane species too.

Finally, all samples of $M$. alba show a (semi-) ring-porous vessel distribution and spiral thickenings in the narrow vessel elements. The origin of the samples is temperate (the Netherlands), subtropical/temperate (South Africa) and tropical montane (India), respectively.

In conclusion, the features of (semi-) ringporosity and spiral thickenings are linked within the genus, and this combination occurs in the temperate and tropical montane areas. The only exception is found in $M$. insignis, occurring in high tropical montane areas (approx. $3000 \mathrm{~m}$ altitude) with diffuse vessels without spiral thickenings.

The parenchyma distribution is strongly dominated by the vessel distribution. The wide earlywood vessels in the temperate species are included in broad bands of marginal (i.e., initial) parenchyma, the small latewood vessels show vasicentric to slightly aliform parenchyma. In the tropical montane taxa the marginal bands are less well developed, and the paratracheal parenchyma is more confluent. Finally, in the tropical lowland species marginal parenchyma is faint, and wavy bands are dominating the parenchyma distribution.

Plecospermum - A semi-ring-porous condition is also found in Plecospermum, a tropical 
taxon of rather dry habitat with seasonal rainfall. As in the species of Maclura, Morus and Broussonetia with a ring-porous vessel distribution, broad bands of marginal (i.e., initial) parenchyma occur. Spiral thickenings were not observed.

Streblus - The two species of Streblus sect. Paratrophis differ in their habitat and habit: $S$. glaber (trees, up to $40 \mathrm{~m}$ tall) occurs in montane forests $(700-2500 \mathrm{~m})$, and $S$. pendulinus (shrubs or small trees, up to $13 \mathrm{~m}$ tall) is found in lowland forests and on sea shores, often under seasonal conditions. The differences in wood anatomy (see Table 4 and Fig. 2) are substantial, and are not easily explained by differences in ecology. Therefore the broad genus concept of Streblus sensu Corner is contradicted (TerWelle, 1985). See further under 'Generic delimitation'.

\section{Habit and wood anatomy}

Among species studied some lianas or climbers occur, viz. Broussonetia kurzii, Maclura cochinchinensis, $M$. brasiliensis, Plecospermum and Malaisia.

A high percentage of vessel tissue through large and/or numerous vessels is a well known characteristic of lianas. This pattern is found in Maclura brasiliensis, Plecospermum, and some of the specimens of Maclura cochinchinensis. Along with large vessels, many narrower vessels in radial chains or irregular clusters of up to 10 pores generally occur. In the temperate specimens of Maclura cochinchinensis, Malaisia and Broussonetia kurzii, the vessel pattern is not liana-like. Maclura cochinchinensis and Malaisia usually start as small shrubs, finally becoming lianas. It is assumed that the samples studied had not reached the stage of liana when they were collected. The same conclusion can be drawn for Broussonetia kurzii. In the outermost part of the small sample the first radial chains of small vessels can be observed, as well as the druses. A mixture of druses and rhombic crystals at the moment the habit becomes liana-like has also been described for some taxa in the Urticaceae (Bonsen \& ter Welle, 1984).

\section{Generic delimitation}

Broussonetia - As already pointed out in the generic description, several suggestions for the taxonomic position of $B$. greveana have been made, i.e., treatment as: a species of the genus Chlorophora (Léandri, 1948); a species of the section Chlorophora in Maclura (Corner, 1962); a species of the genus Allaeanthus (Capuron, 1972); a species of section Allaeanthus in Broussonetia (Berg, 1977a).
Berg transferred the species of Maclura sect. Chlorophora (except $M$. tinctoria) to the genus Milicia. In his description of Broussonetia greveana $(1977 \mathrm{a})$ he mentions the resemblance between this species and Chlorophora (Milicia) excelsa. Wood anatomically, both species are rather similar, but in Milicia the parenchyma pattern is more confluent and in wavy bands. The resemblance between Broussonetia greveana and $B$. luzonica is very high in all wood anatomical features. Capuron's decision to assign these species to the same taxon (the genus Allaeanthus) is thus fully supported.

A comparison of the wood anatomical data of section Broussonetia and section Allaeanthus (Table 1) reveals that the occurrence of spiral thickenings can be used to distinguish between the two sections: spirals occur only in section Broussonetia. The fact that this difference cannot be fully explained by ecological differences (see above) might be an indication of some taxonomic value of this feature. At first view, the two sections seem to differ in their vessel distribution and in parenchyma distribution, too. However, these features are in part related to geographical and ecological factors. It may be concluded that the decision to include the former genus Allaeanthus as a separate section in Broussonetia is, at least, not contradicted by the wood anatomical differences.

Maclura - Corner (1962) included four genera in Maclura: Cardiogyne, Chlorophora, Cudrania and Maclura. Berg (1977a) modified this concept. He included also Plecospermum, but assigned the two African species of Chlorophora to Milicia (1982), following the conclusions of Kloos (1982) who reported considerable differences in the leaf anatomy between the African and Neotropical species.

Maclura sect. Chlorophora and Milicia: As in macromorphological and leaf anatomical attributes, the wood anatomy reveals a number of differences between Milicia and Maclura tinctoria (see Table 6). Thus, the distinction of two taxa in the former genus Chlorophora is supported.

Maclura, Cardiogyne, Chlorophora and $\mathrm{Cu}$ drania: These four sections of Maclura have many characters in common. Most striking is the occurrence of chambered crystalliferous parenchyma strands, with up to 16 crystals in a longitudinal row. In the section Cardiogyne this feature is less well developed. Crystalliferous parenchyma strands are very scarce in the Moraceae. Besides the taxa already mentioned, they were observed in Plecospermum, in Streblus sections Paratrophis, Phyllochlamus and Sloetia, and in Trophis sect. Calpido- 
Table 6. Some wood anatomical features of Milicia and Maclura sect. Chlorophora.

$\begin{array}{lccccccc}\text { Species } & \begin{array}{c}\text { vessel member } \\ \text { length }(\text { in } \mu \mathrm{m})\end{array} & \begin{array}{c}\text { pit size } \\ \text { (in } \mu \mathrm{m})\end{array} & \begin{array}{c}\text { fibre length } \\ \text { (in } \mu \mathrm{m})\end{array} & \begin{array}{c}\text { ray frequency } \\ \text { (per mm) }\end{array} & \begin{array}{c}\text { multiseriate ray } \\ \text { height (in } \mu \mathrm{m})\end{array} & \begin{array}{c}\text { crystal } \\ \text { distribution }\end{array} & \begin{array}{c}\text { ray type } \\ \text { (Kribs) }\end{array} \\ \text { Milicia } & 350-400 & 10-12 & 1050-1425 & 4-6 & 170-400 & \text { u, a } & \text { III } \\ \text { Maclura tinctoria } & 250-320 & 7-8 & 810-1040 & 6-9 & 315-460 & \text { ac, p } & \text { ho }\end{array}$

Legends: Crystals: $\mathrm{a}=$ in axial parenchyma cells; $\mathrm{ac}=$ in chambered parenchyma cells; $\mathrm{p}=$ in procumbent ray cells; $\mathbf{u}=$ in square and upright ray cells. - Ray type: I, II, III = heterogeneous types according to Kribs (1968); ho = homogeneous, i.e., composed of procumbent cells only.

chlamys. However, the length of the longitudinal rows in these taxa is often more limited, even more so than in Cardiogyne. The ray type of Maclura s.l. is homogeneous to occasionally heterogeneous type III, a ray type which is rather uncommon in the Moraceae. The section Cardiogyne and Maclura brasiliensis of section Maclura differ from the other taxa in having ray type I or II. The range of variation of mean fibre lengths and vessel element lengths for all sections is narrow when compared with the other Moreae studied, and the values themselves are low. The basic parenchyma distribution pattern in Maclura s.l. is vasicentric-aliform and in short wavy bands combined with marginal parenchyma. The marginal bands were not observed in section Cardiogyne and Maclura brasiliensis. The parenchyma distribution in Chlorophora is usually less wavy-banded, and occasionally unilateral.

The four sections of Maclura sensu Corner, viz., Cudrania, Cardiogyne, Chlorophora and Maclura have many characters in common. Section Cardiogyne and Maclura brasiliensis deviate somewhat, but resemble each other in many features. Based on wood anatomical evidence the genus concept of Maclura s.l. is supported, with the remark that more material of Cardiogyne and Maclura brasiliensis should be studied before these two taxa are definitely included in Maclura.

Maclura-Plecospermum: Plecospermum only deviates from Maclura s.l. in the high number of vessels per sq. mm. As this may be a result of the climbing habit of Plecospermum, the suggestion of Berg (1983) to include this taxon in Maclura s.l. is fully supported by its wood anatomical features.

Morus, - The circumscription and subdivision of Morus are difficult (Berg, 1977a). A recent monograph is not available. The species studied are from temperate and tropical areas. The wood anatomical differences are mainly correlated with the geographical distribution and ecological variation (see above). Within this genus, Morus mesozygia can easily be identified by its parenchyma distribution in confluent and wavy bands.

Streblus (cf. Table 4 and Fig. 2) - Streblus sensu Corner: The wood anatomical features of the individual species of Streblus vary within small limits, notwithstanding the differences in locality and habitat. However, the variation between the species of Streblus sensu Corner approaches the full range reported for all other taxa studied here! Parenchyma distribution, crystal distribution, silica distribution, number of vessels per sq. mm, vessel diameter and size of the intervascular pits all vary tremendously. The wood anatomy does not support the broad genus concept of Streblus sensu Corner. A genus rank for most species studied seems more justified.

Streblus and Sloetiopsis: Corner (1962) mentioned the possibility of including Sloetiopsis in his genus concept of Streblus s.l. Berg (pers. comm.) hesitates to accept this idea. From a wood anatomical point of view Sloetiopsis is the most deviating taxon in the Moreae under study here. The very small intervascular pits (c. $2 \mu \mathrm{m}$ ) and the frequent narrow concentric apotracheal parenchyma bands suggest an isolated position within the Moreae.

Trophis - Corner (1962) included two taxa, until then recognised as individual genera, viz. Calpidochlamys and Maillardia, in Trophis s.l. According to Berg (1977a) Calpidochlamys and Maillardia seem to be related, but he hesitates to include these taxa in Trophis.

Trophis: Corner (1962) assigned T. mexicana and $T$. americana $(=T$. racemosa according to Burger, 1962) to two different subgenera. Burger (1962) monographed Trophis (the Neotropical species), and concluded that these two 
species are closely related. The wood anatomical data fully support Burger, notwithstanding small quantitative differences.

Trophis, Calpidochlamys and Maillardia: The wood anatomical differences between these taxa are given in Table 5. Section Trophis and section Maillardia are similar in the concentric parenchyma bands, but differ in vessel diameter, size of the intervascular pits, length of vessel members and fibres, and number of rays $/ \mathrm{mm}$. Thus, in our opinion the inclusion of Maillardia in Trophis (Corner, 1962) is not supported. Berg's suggestion (pers. comm.) to exclude Maillardia seems more justified. In section Calpidochlamys, the parenchyma bands are much less dominating and more widely spaced. Other differences are found in the number of vessels, the size of the intervascular pits, the fibre length, and the crystal distribution, especially the presence of crystalliferous strands in Calpidochlamys. Consequently, Berg's idea (pers. comm.) to exclude this taxon from Trophis s.l., too, seems justified. According to Berg (1977a) Maillardia and Calpidochlamys are probably closely related. The wood anatomical differences between these two taxa are as substantial as between them and section Trophis/ subgenus Prototrophis, respectively.

Trophis and Olmedia: Berg (1983) included Olmedia in Trophis s.l. Corner (1962) assigned Olmedia to the tribe Olmedieae, by Berg renamed as the tribe Castilleae (1977b) after the exclusion of Olmedia. Olmedia differs from Trophis in the occurrence of septate fibres, radial latex tubes and vitreous silica in the vessels. In addition, the rhombic crystals in the rays and parenchyma cells of Trophis are lacking in Olmedia and the vessel members are longer. Thus, Olmedia should not be included in Trophis.

Malaisia and Pachytrophe - The wood anatomical features of Malaisia and Pachytrophe each vary within narrow limits. These genera therefore seem to be well defined.

\section{Taxonomy of the Moreae}

A proposal for a classification of the Moreae with urticaceous stamens is rather unrealistic, as this paper only deals with part of this tribe. A comparison with the other genera of the tribe (those without urticaceous stamens) is essential, as in the literature several classifications have been proposed where genera of both groups have been treated as close allies. We will return to this point in a subsequent paper (Ter Welle et al., in preparation).

\section{References}

Baillon, H. 1895. Histoire physique naturelle et politique de Madagascar 35 (ed. A. Grandidier). Histoire naturelle des plantes 5. Atlas 3. Paris.

Bentham, G. \& J.D. Hooker. 1880. Urticaceae. Genera Plantarum. London.

Berg, C.C. 1972. Olmedieae, Brosimeae (Moraceae). Flora Neotropica, Monograph no. 7. Hafner Publ. Comp., New York.

- 1973. Some remarks on the classification and differentiation of Moraceae. Meded. Bot. Mus. Herb. Rijksuniversiteit Utrecht 386: $1-10$.

- 1977a. Revisions of African Moraceae (excluding Dorstenia, Ficus, Musanga and Myrianthus). Bull. Jard. Bot. Nat. Belg. 47: 267407.

- 1977b. The Castilleae, a tribe of the Moraceae, renamed and redefined due to the exclusion of the type genus Olmedia from the 'Olmedieae'. Acta Bot. Neerl. 26: 73-82.

- 1982. The reinstatement of the genus Milicia Sim (Moraceae). Bull. Jard. Bot. Nat. Belg. 52: 225-229.

- 1983. Dispersal and distribution in the Urticales - an outline. In: Dispersal and distribution (ed. K. Kubitzki). Publ. Comp. Paul Parey, Hamburg, Berlin.

Bonsen, K.J. \& B.J.H. ter Welle. 1984. Systematic wood anatomy and affinities of the Urticaceae. Bot. Jahrb. 105: 49-71.

Burger, W.C. 1962. Studies in new world Moraceae: Trophis, Clarisia, Acanthinophyllum. Ann. Missouri Bot. Gard. 49: 1-34.

Capuron, R. 1972. Contribution à l'étude de la flore forestière de Madagascar. Adansonia sér. 2, 12: 375-388.

Corner, E.J.H. 1962. The classification of Moraceae. Gard. Bull. Sing. 19: 187-251.

Engler, A. 1888. Moraceae. In: Die natürlichen Pflanzenfamilien (ed. A. Engler \& K. Prantl). Engelmann, Leipzig.

Graaff, N.A. van der \& P. Baas. 1974. Wood anatomical variation in relation to latitude and altitude. Blumea 22: 101-121.

Kaastra, R.C. 1972. Revision of Chlorophora (Moraceae) in America. Acta Bot. Neerl. 21: 657-670.

- 1973. Description and taxonomic position of Maclura brasiliensis (Moraceae). Acta Bot. Neerl. 22: 69-74.

Kloos, A. 1982. Multidisciplinary systematic research in Moreae (Moraceae) - Leaf anatomy of the Maclura-group. Acta Bot. Neerl. 31: 145. 
Koek-Noorman, J., S.M.C. Topper \& B.J.H. ter Welle. 1984. The systematic wood anatomy of Moraceae (Urticales). I. Tribe Castilleae. IAWA Bull. n.s. 5: 183-195.

Kribs, D. A. 1968. Commercial foreign woods on the American market. Dover Publ., New York.

Léandri, J. 1948. Contribution à l'étude des 'Artocarpoideae' de Madagascar. Not. Syst. 13: $171-181$.
Mennega, A. M.W. \& M. Lanzing-Vinkenborg. 1977. On the wood anatomy of the tribe 'Olmedieae' (Moraceae) and the position of the genus Olmedia R. \& P. Acta Bot. Neerl. 26: $1-27$.

Welle, B.J.H. ter. 1985. Wood anatomy of Streblus s.1. (Moraceae). Proc. Forest Prod. Res. International, Pretoria 1 (16-6): 1-7. 